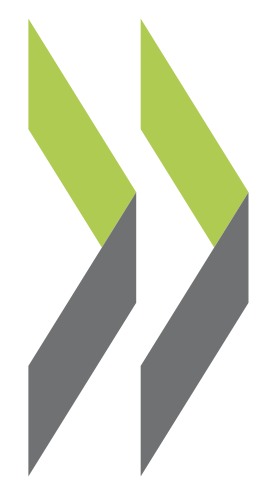

OECD Economics Department Working Papers No. 306

\title{
Standard Shocks \\ in the OECD Interlink Model
}

Thomas Dalsgaard,

Christophe André, Pete Richardson 
Organisation de Coopération et de Développement Economiques

Organisation for Economic Co-operation and Development

06-Sep-2001

ECONOMICS DEPARTMENT

English text only

STANDARD SHOCKS IN THE OECD INTERLINK MODEL

ECONOMICS DEPARTMENT WORKING PAPERS NO. 306

by

Thomas Dalsgaard, Christophe André and Pete Richardson

Most Economics Department Working Papers beginning with No. 144 are now available through OECD's Internet Web site at http://www.oecd.org/eco/eco. 


\begin{abstract}
RÉSUMÉ
One of the OECD Economic Department's key vehicles for analysing effects and international spillovers of macroeconomic policy as well as assessing risks to the global outlook is the macroeconometric model, INTERLINK. In the context of the Department's regular projection exercises the model performs a variety of functions. These include 1) contributing to the construction and co-ordination of individual country projections; 2 ) the production of globally consistent trade projections; and 3) simulations to explore the short- to medium-term consequences of alternative economic conditions and policy assumptions. This paper briefly describes the main features of the current version of INTERLINK and presents the results of a number of standard macroeconomic shocks. These simulation results reflect the combination of unadjusted model properties and the specific stylised policy assumptions made. In the course of more routine policy analysis with the model at the OECD, these are augmented by specific additional judgements and assumptions concerning policy objectives as well as a range of other economic factors.
\end{abstract}

JEL classification: C5.

Keywords: Macroeconometric model; forecasting; simulations.

$$
* * * * * *
$$

Le modèle macro-économétrique INTERLINK est l'un des principaux outils du Département des affaires économiques de l'OCDE pour analyser les effets directs et les répercussions internationales des politiques économiques et pour évaluer les risques pesant sur les perspectives globales. Dans le cadre des exercices réguliers de prévision, le modèle remplit diverses fonctions parmi lesquelles : 1) contribuer à la construction et à la coordination des prévisions de chaque pays; 2) produire des prévisions du commerce international globalement cohérentes; et 3) réaliser des simulations pour explorer les conséquences à court et à moyen terme de différentes hypothèses sur l'environnement économique et les politiques économiques. Ce document de travail décrit brièvement les principales caractéristiques de la version actuelle d'INTERLINK et présente les résultats de chocs macro-économiques standards. Ces résultats de simulations reflètent à la fois les propriétés intrinsèques du modèle et des hypothèses de politique spécifiques. Dans le cadre de l'analyse courante des politiques avec le modèle à l'OCDE, ces dernières sont enrichies d'appréciations et hypothèses supplémentaires sur les objectifs des politiques, ainsi que sur un certain nombre d'autres variables économiques.

Classification JEL : C5.

Mots-clés : modèle macro-économétrique ; perspectives ; simulations.

\title{
Copyright: OECD 2001
}

Applications for permission to reproduce or translate all, or part of, this material should be made to: Head of Publications Service, OECD, 2 rue André Pascal, 75775 PARIS CEDEX 16, France. 


\section{TABLE OF CONTENTS}

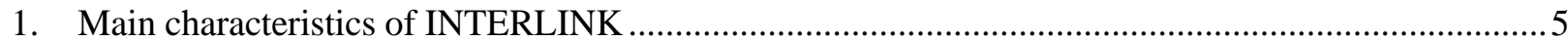

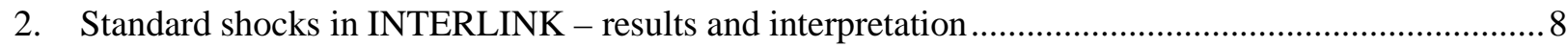



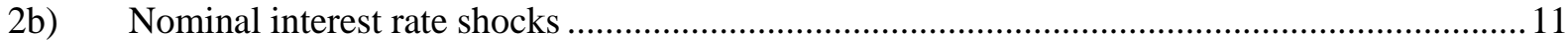

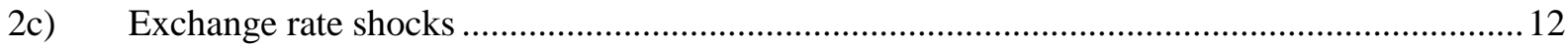

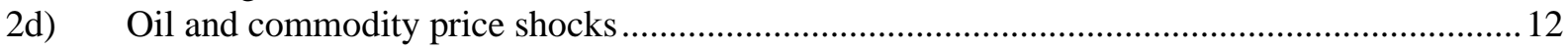

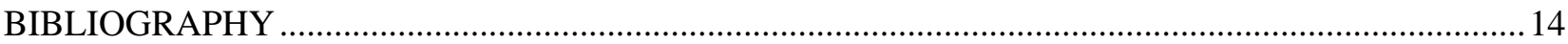

\section{Tables}

1. Effects on real GDP from a government spending shock - country-specific versus a global shock

2. Selected properties of INTERLINK models for the major seven countries

3. Effects of a government spending increase of 1 per cent of GDP

- with and without international spillover effects

Annex Standard Shocks 


\section{STANDARD SHOCKS IN THE OECD INTERLINK MODEL}

\section{Thomas Dalsgaard, Christophe André and Pete Richardson ${ }^{1}$}

1. One of the OECD Economic Department's key vehicles for analysing effects and international spillovers of macroeconomic policy as well as assessing risks to the global outlook is the macroeconometric model, INTERLINK. In the context of the Departments regular projection exercises the model performs a variety of functions. These include 1) contributing to the construction and co-ordination of individual country projections; ${ }^{2}$ 2) the production of globally consistent trade projections; and 3 ) simulations to explore the short- to medium-term consequences of alternative economic conditions and policy assumptions.

2. Given the wide variety of uses which INTERLINK serves, it has been necessary to recognise an important balance between statistical goodness-of-fit, structural simplicity and theoretically plausible behaviour in the development of the model. For a macroeconometric model to be useful for policy analyses, which go beyond short-term forecasting requirements, particular attention must be paid to its long-term equilibrium properties and stability with respect to output, employment and inflation. At the same time, appropriate econometric methods are needed to ensure that short-term dynamic properties and underlying estimated properties are consistent with data and well-determined.

3. This paper briefly describes the main features of the current version of INTERLINK and presents the results of a number of standard macroeconomic shocks. ${ }^{3}$

1. The authors are, respectively, senior economist, statistical assistant and head of division in the Economics Department at the OECD. They would like to thank Michael Feiner, Jørgen Elmeskov, Dave Turner, Dave Rae and Aaron Drew for comments and suggestions. Special thanks goes to Jackie Gardel for secretarial assistance.

2. The main role for INTERLINK in shaping individual country projections is to assist the country experts in the early phases of the forecast round, where model simulations of the effects of changed exogenous assumptions (i.e. interest rates; exchange rates; oil and non-oil commodity prices; and non-OECD import volumes) are discussed at Departmental meetings. A genuine model based projection is not carried out with INTERLINK, but a regional model-based projection is produced by the so-called "Small model" before the beginning of each projection round to help stimulate internal discussions on the global outlook. The Small model is a highly aggregated model including four regions: the United States, Japan, the euro area and the rest of the world. Rae and Turner (2001) gives a detailed documentation of the Small model and its properties.

3. A revised version of INTERLINK is currently being prepared by the Economics Department, incorporating important improvements such as the ability to model forward-looking behaviour as well as integrating more directly results from research projects within the Department, notably the recent change in methodology for estimating structural unemployment (Richardson et al., 2000). 


\section{Main characteristics of INTERLINK}

4. INTERLINK follows the tradition of many other macroeconomic models, combining short-term "keynesian" features with long-term neo-classical properties. In particular, the presence of real and nominal rigidities in the equations describing wage and price setting behaviour generally imply that a protracted period of adjustment occurs before output and employment returns to potential following a shock.

5. A country-specific model exists for each OECD Member country, ${ }^{4}$ while non-OECD countries are modelled in more rudimentary country blocks, primarily with the aim of capturing global trade linkages. The individual country models are linked through the traditional channels of trade, financial flows and exchange rates. The elaborate trade block in INTERLINK allows a particular focus on this linkage between OECD countries as well as between OECD countries and non-OECD regions. The structure of the trade block also ensures overall global consistency of trade volumes by imposing that the growth of import volumes is equal to the growth of export volumes at the global level.

6. The core of each country model consists of: $a$ ) a production function determining output in the long term; $b$ ) a wage-price block, which in combination with factor demand equations (for capital and labour) essentially determines the speed of adjustment following a shock; $c$ ) behavioural equations for private consumption as well as for prices and volumes of imports and exports. These equations are mostly estimated on a country-by-country basis, although the key export equations are estimated using pooled estimation techniques. ${ }^{5}$

7. The supply side of most country models is determined by a constant-returns-to-scale Cobb-Douglas production function with capital and labour as production factors. ${ }^{6}$ Labour is assumed to be a homogenous production factor and no distinction is made between skilled and unskilled labour. Technological progress is disembodied and specified in terms of a labour efficiency index (which, given the Cobb-Douglas specification, can easily be rewritten as a total factor productivity index). Demand for labour and capital is determined by profit maximisation of the firms, implying that the long-run labouroutput ratio depends on real wage costs, while the long-run capital-output ratio depends on the real user cost of capital.

8. Prices are determined as a constant mark-up over marginal costs in the long term. ${ }^{8}$ In the short run, prices are sensitive to demand pressure and may therefore deviate from unit costs. Moreover, costs do not feed through instantaneously to prices due to nominal rigidities. Real wages are assumed to be determined in a wage-bargaining framework, hence depending on the level of trend labour productivity as well as the rate of unemployment. The adjustment of real wages to productivity changes as well as the responsiveness of real wages to changes in unemployment are sluggish due to real rigidities. In the long run, there is a unique equilibrium rate of unemployment consistent with stable inflation. This implicit equilibrium rate of unemployment (or the NAIRU) in INTERLINK is influenced by the rate of growth of trend labour productivity as well as the magnitude of the real rigidity in the wage equation.

4. $\quad$ Except for Luxembourg.

5. See Murata, Turner, Rae and Le Fouler (2000).

6. See Turner et al. (1996) for more details. Japan is an exception since the Cobb-Douglas restriction is found not to be statistically acceptable. Hence, a CES technology specification is applied in the case of Japan.

7. In practice, the real user costs of capital pins down the capital/output-ratio, which in turn determines the labour/output-ratio and thus the level of the real wage (for a given NAIRU, $c f$. below).

8. As the production technology assumed is constant returns to scale for all countries, marginal and average costs are identical. 
9. Private consumption depends on disposable income and wealth, proxied by the real interest rate and the rate of inflation. ${ }^{9}$ Business investment is basically determined by accelerator effects in the short term (higher output growth stimulates investment) while the real user cost of capital determines the long-term desired capital/output ratio and hence the rate of long-term level of investment. Residential investment depends on real disposable incomes and real interest rates. Exports are linked to market growth and price competitiveness while imports depend on total expenditure and price competitiveness. ${ }^{10}$

10. The above-mentioned features basically determine the outcome of simulations with INTERLINK. A main characteristic of most country models is that autonomous demand changes have a substantial impact on output and unemployment in the short- to medium term but are crowded out in the long term. An autonomous rise in demand is eventually offset by the negative impact of temporarily higher inflation (caused by higher wage costs as the labour market becomes tighter as well as the direct effect of higher capacity utilisation on prices) on consumption and net exports. As a consequence, unemployment returns to its baseline level and output is fully determined by supply-side factors in the long term. The speed of adjustment is evidently influenced by the assumptions made about monetary and fiscal policy.

11. The multi-country dimension of the model is of particular importance for the short- to medium-term simulation properties. For example, in the case of a simultaneous autonomous domestic demand increase in all OECD countries, the second-round effects on output of individual countries are not only affected negatively by import leakages, but also positively by the increased foreign demand for exports. This means that the effects, at least initially, are much more substantial than if only one country expands demand (Table 1). Another example is an oil price increase, which adversely affects output in most OECD countries (except for net exporters of oil such as Canada, Mexico and Norway). In this case, the reduction in domestic demand due to the terms-of-trade loss is exacerbated by the drop in export market growth. On the other hand, the model also captures the positive effects from the gradual increase in import volumes of oil producing non-OECD regions.

\section{Table 1. Effects on real GDP from a government spending shock - country-specific versus a global shock}

Per cent deviation from baseline

\begin{tabular}{|c|c|c|c|c|c|}
\hline Year & 1 & 2 & 3 & 4 & 5 \\
\hline \multicolumn{6}{|c|}{ Country-specific shocks: } \\
\hline United States & 1.1 & 1.0 & 0.5 & 0.2 & 0.1 \\
\hline Japan & 1.7 & 1.1 & 0.4 & 0.2 & 0.5 \\
\hline Euro area & 1.2 & 0.9 & 0.5 & 0.2 & 0.1 \\
\hline \multicolumn{6}{|l|}{ Global shock: } \\
\hline United States & 1.5 & 1.3 & 0.7 & 0.3 & 0.2 \\
\hline Japan & 2.6 & 1.9 & 0.6 & 0.3 & 1.0 \\
\hline Euro area & 1.9 & 1.5 & 0.7 & 0.4 & 0.3 \\
\hline
\end{tabular}

Note: In the country-specific shocks, government spending is raised by 1 per cent of GDP only in the country in question. In the global shock, government spending is raised by 1 per cent of GDP simultaneously in all OECD countries. Nominal exchange rates and real interest rates are kept constant.

9. The presence of inflation in the consumption equation can be perceived as a proxy for real balance effects (higher inflation reduces real balances and hence consumption). The short-term interest rate mainly reflects a discount effect (the lower interest rate, the higher is the present value of the future income stream of financial assets) but could also work through direct effects on disposable income and saving behaviour.

10. The specification of the demand side within INTERLINK is described in more detail in Richardson (1988). 
12. Cross-country differences in the simulation results reflect a combination of various factors, including the sacrifice ratio, the elasticity of imports to total expenditure, the short-run propensity to consume out of disposable income, the sensitivity of consumption to inflation, the elasticity of investment to output changes and the sensitivity of exports to competitiveness changes. These characteristics are summarised below for the major seven countries (Table 2). ${ }^{11}$

Table 2. Selected properties of INTERLINK models for the major seven countries

\begin{tabular}{lccccccc}
\hline & $\begin{array}{c}\text { Sacrifice } \\
\text { ratio }\end{array}$ & $\begin{array}{c}\text { Response of } \\
\text { real wage to } \\
\text { changes in } \\
\text { unemployment }\end{array}$ & $\begin{array}{c}\text { Response of } \\
\text { private } \\
\text { consumption } \\
\text { to inflation }\end{array}$ & $\begin{array}{c}\text { Short-run } \\
\text { propensity to } \\
\text { consume out } \\
\text { of disposable } \\
\text { income }\end{array}$ & $\begin{array}{c}\text { Short-run } \\
\text { response of } \\
\text { capital stock } \\
\text { to increase in } \\
\text { output }\end{array}$ & $\begin{array}{c}\text { Long-run } \\
\text { elasticity of } \\
\text { imports to } \\
\text { increased } \\
\text { total } \\
\text { expenditure }\end{array}$ & $\begin{array}{c}\text { Long-run } \\
\text { price } \\
\text { elasticity of } \\
\text { exports }\end{array}$ \\
\hline $\begin{array}{l}\text { United States } \\
\text { Japan }\end{array}$ & 1.0 & 2.5 & -0.2 & 0.3 & 0.05 & 2.5 & -0.6 \\
Germany & 0.1 & 21.6 & -0.3 & 0.6 & 0.09 & 1.9 & -1.7 \\
France & 1.1 & 2.5 & -0.1 & 0.5 & 0.06 & 2.3 & -1.0 \\
Italy & 1.0 & 4.2 & -0.4 & 0.2 & 0.06 & 2.0 & -1.0 \\
United Kingdom & 8.6 & 1.2 & -0.1 & 0.2 & 0.04 & 1.7 & -1.0 \\
Canada & 5.7 & 0.5 & -0.2 & 0.4 & 0.04 & 1.8 & -1.0 \\
\hline
\end{tabular}

Note: The sacrifice ratio measures the cumulative percentage point increase (decrease) in the unemployment rate required to bring about a reduction (increase) in the annual rate of inflation of 1 percentage point following a demand shock. The unemployment response of real wages measures the per cent change in real wages given a change in unemployment of 1 percentage point. The response of private consumption to inflation measures the per cent change in the volume of consumption after two years given an increase in inflation of 1 percentage point. The short-run propensity to consume measures the first-period per cent response of private consumption to a change in real disposable income of 1 per cent. The short-run response of the capital stock to an increase in output measures the first-period per cent response of the capital stock to a 1 per cent change in output. The elasticity of import to increased total expenditure show the per cent increase in manufactured import volumes given an increase in domestic demand of 1 per cent. The price elasticity of exports show the per cent response of manufactured export volumes to a change in relative prices of 1 per cent.

13. It is difficult, based on Table 2, to draw general conclusions on the adjustment path of the individual country models following a shock. Focus should be on the properties of the whole system rather than properties of single equations. For instance, the isolated effect of the high estimated sacrifice ratios for the United Kingdom and Italy is to slow down the speed of adjustment in those countries. ${ }^{12}$ On the other hand, the large sensitivity to inflation in the UK consumption function contributes to a faster adjustment in that country, while adjustment in Italy is further protracted due to the low consumption response to inflation. The estimated low sacrifice ratio for Japan implies that unemployment changes only little in the face of demand shocks and is an indication that crowding out is very fast. But the low sacrifice ration merely reflects the historically low variation in unemployment in this country, which again is an indication of large labour supply responses to changes in demand pressure. Hence, when defining the sacrifice ratio in terms of output decline needed to bring about a given reduction in inflation, the model for Japan is more or less in line with the other major countries.

11. For a more comprehensive discussion on how these features influence the adjustment path of individual countries, see Turner et al. (1996).

12. There are reasons to interpret the high sacrifice ratio for the United Kingdom with particular caution since the estimated coefficient measuring the unemployment effect on wages shows a tendency to increase since the early 1980s (reflecting structural reform on the UK labour market). Hence, the estimated average of this coefficient is almost certainly too low and the sacrifice ratio too high. 
14. The response of the capital stock to changes in output also has a major influence on simulation properties. On the one hand, the adjustment is very slow: on average across the major seven countries, the median lag of the capital stock with respect to a change in output is about 20 years. This sluggish adjustment implies that it often takes ten years or more before a new equilibrium is reached following a shock. On the other hand, the implied adjustment of investment following a shock to output is distinctly lively, and the strong accelerator response from investment leads to pronounced cyclical responses in most model simulations. This is particularly the case for Japan, where the short-run response of investment to output changes is twice as large a in the other major countries. Another significant influence on the adjustment path is the short-run propensity to consume out of disposable income. This is quite low in France and Italy, implying a more subdued initial consumption response to e.g. a tax cut in these countries than elsewhere among the major seven economies. The import leakage also impinges substantially on simulation results. The long-run elasticity of imports to total expenditure is around 2 in most countries, albeit slightly higher in the United States. Finally, a significant feature for Japan in many simulations is the greater sensitivity of exports to changes in price competitiveness, which is only partly offset by a low sensitivity of export prices to domestic deflators.

15. Some caveats are worthwhile bearing in mind when interpreting simulation results. First, the model does not allow for forward looking behaviour even though expectations about future changes in policies or market circumstances are often as important as the events themselves. This applies not only to financial variables such as interest- and exchange rates, but also to wage- and price formation, investment decisions, etc. Second, most of INTERLINK's main behavioural equations were last estimated in the mid-1990s, and may therefore not adequately capture the extent to which more recent systemic changes might have influenced economic behaviour in various OECD countries.

\section{Standard shocks in INTERLINK - results and interpretation}

16. Annex Tables A1-A21 show the results of a range of standard simulations on INTERLINK, discussed in more detail below. The policy assumptions underlying each simulation are indicated in the relevant table. All simulations are run in "multi-country mode" implying that international linkages are switched on. This means, for example, that a demand increase in the United States will cause demand in the rest of the world to increase as well, which then feeds-back on US exports and the US economy in general. However, in order to indicate the magnitude of international spillovers, results are also reported for some simulations run in "single-country mode".

17. It is emphasised that these simulation results reflect the combination of unadjusted model properties and the specific stylised policy assumptions made. In the course of more routine policy analysis with the model at the OECD, these are augmented by specific additional judgements and assumptions concerning policy objectives and a range of other economic factors relevant to the conjunctural situation and, in particular, market reactions and expectations.

\section{2a) Shocks to government spending and taxation}

18. A permanent rise in government consumption expenditure (Tables A1-A3) leads to an immediate increase in domestic demand and real GDP. The initial increase in GDP peaks in the first or second year when the accelerator response from investment is strongest. As unemployment falls below its equilibrium level and demand pressure increases (measured by the intensity of factor utilisation, i.e. actual GDP divided by potential GDP), wages start increasing and inflation picks up. The peak in inflation typically lags behind the peak in the output response due to real and nominal rigidities. The increase in inflation leads to an elimination of the initial output gain through two principle transmission mechanisms: 
the initial worsening of competitiveness (since nominal exchange rates are assumed unchanged) leads to declining net exports - hence deteriorating the current account - and higher inflation also has a direct negative effect on consumption. In the long term, real GDP, unemployment and inflation return to their baseline values, while the price level is permanently higher. In other words, there is complete "crowding-out" of private expenditures by public expenditures. For most countries, the long-run equilibrium is reached within a ten-year horizon, although there may be exceptions due to long lags in the adjustment of the capital stock.

19. The effect on other regions/countries of a government spending shock comes through increased export markets as well as gains in competitiveness (even with fixed nominal exchange rates as inflation temporarily rises most in the country where the fiscal expansion takes place). The result is increased GDP levels, higher inflation and improved current accounts in other countries/regions. ${ }^{13}$ The magnitude of these effects depends on the size and openness of the country of the policy expansion as well as the effect of the policy expansion on GDP and inflation in that country. Tables A1-A3 illustrates how a US government spending shock has larger effects on Japan and the euro area than vice versa.

20. Comparing the results of a government spending shock across the United States, Japan and the euro area, the impact effect is highest in Japan, reflecting mainly the high short-term sensitivity of investment to output changes. Japan's GDP increases by around $13 / 4$ per cent in the impact following a 1 per cent of GDP increase in government expenditure. Inflation increases by $1 / 2$ percentage point in the first year following the shock and 1/1/2 percentage points in the second year. For the United States and the euro area, the overall fiscal multiplier is just above one: GDP increases by 1.1 per cent and 1.2 per cent, respectively, in the first year following a government spending shock. Over the medium term, crowding out of exports is stronger in Japan than elsewhere due to the high sensitivity of exports to the real appreciation of the Yen following the rise in domestic inflation. The United States, on the other hand, has more pricing power on world markets and is hence able to pass on a larger fraction of increased domestic costs to importing countries. However, the relatively large long-run import elasticity in the United States implies that the current account deteriorates by the same proportion as in the other major regions. For all three major regions, but particularly in Japan, a twin-deficit (current account and government budgets) of quite substantial proportions are in place after five years following a discretionary government spending increase of 1 per cent of GDP. ${ }^{14}$

21. To gauge the effect of international spillovers, the government spending shock has been simulated when international feed-back mechanisms are switched off. The differences to the previous results are mainly that single-country simulations do not take into account changes in overall export markets due to substitution in other countries between imports from the country where the shock took place and domestically produced goods, nor do they take into account how a slowdown or upturn in one country may affect total demand in other regions and hence feed-back on the country where the shock originated. However, such spillover-effects are relatively small in INTERLINK (Table 3). ${ }^{15}$

13. A particular feature for Japan is that, following a shock to US government spending, Japan's government accounts deteriorate slightly despite higher domestic activity. The reason is that increases in domestic inflation trigger higher nominal interest rates to keep real interest rates unchanged. With Japan's high government debt burden, the ensuing interest expenditure increases dominate the positive budgetary effects from higher activity.

14. The deterioration of government balances after five years is almost twice as large in Japan as in the United States or the euro area. This is mainly due to increased interest payments.

15. This finding is in line with that of e.g. Hall and Whitley (1999). 
Table 3. Effects of a government spending increase of 1 per cent of GDP - with and without international spillover effects

\begin{tabular}{|c|c|c|c|c|c|}
\hline Year & 1 & 2 & 3 & 4 & 5 \\
\hline \multicolumn{6}{|l|}{ United States } \\
\hline \multicolumn{6}{|l|}{ Linked } \\
\hline Real GDP & 1.1 & 1.0 & 0.5 & 0.2 & 0.1 \\
\hline Inflation & 0.2 & 0.7 & 1.0 & 1.2 & 1.2 \\
\hline \multicolumn{6}{|l|}{ Unlinked } \\
\hline Real GDP & 1.0 & 0.8 & 0.5 & 0.3 & 0.1 \\
\hline Inflation & 0.1 & 0.5 & 0.8 & 0.9 & 0.9 \\
\hline \multicolumn{6}{|l|}{ Japan } \\
\hline \multicolumn{6}{|l|}{ Linked } \\
\hline Real GDP & 1.7 & 1.1 & 0.4 & 0.2 & 0.5 \\
\hline Inflation & 0.5 & 1.4 & 0.5 & -0.1 & 0.4 \\
\hline \multicolumn{6}{|l|}{ Unlinked } \\
\hline Real GDP & 1.6 & 1.1 & 0.5 & 0.3 & 0.4 \\
\hline Inflation & 0.4 & 1.4 & 0.5 & 0.0 & 0.4 \\
\hline \multicolumn{6}{|l|}{ Germany } \\
\hline \multicolumn{6}{|l|}{ Linked } \\
\hline Real GDP & 1.1 & 0.7 & 0.2 & 0.0 & -0.2 \\
\hline Inflation & 0.2 & 0.3 & 0.5 & 0.7 & 0.7 \\
\hline \multicolumn{6}{|l|}{ Unlinked } \\
\hline Real GDP & 0.9 & 0.5 & 0.1 & -0.1 & -0.2 \\
\hline Inflation & 0.2 & 0.2 & 0.4 & 0.5 & 0.5 \\
\hline \multicolumn{6}{|l|}{ France } \\
\hline \multicolumn{6}{|l|}{ Linked } \\
\hline Real GDP & 0.6 & 0.6 & 0.5 & 0.4 & 0.2 \\
\hline Inflation & 0.1 & 0.4 & 0.6 & 0.6 & 0.6 \\
\hline \multicolumn{6}{|l|}{ Unlinked } \\
\hline Real GDP & 0.6 & 0.5 & 0.4 & 0.3 & 0.1 \\
\hline Inflation & 0.1 & 0.4 & 0.5 & 0.6 & 0.6 \\
\hline \multicolumn{6}{|l|}{ Italy } \\
\hline \multicolumn{6}{|l|}{ Linked } \\
\hline Real GDP & 0.9 & 0.6 & 0.3 & 0.2 & 0.0 \\
\hline Inflation & 0.3 & 0.7 & 0.5 & 0.5 & 0.4 \\
\hline \multicolumn{6}{|l|}{ Unlinked } \\
\hline Real GDP & 0.8 & 0.5 & 0.3 & 0.1 & -0.2 \\
\hline Inflation & 0.2 & 0.6 & 0.5 & 0.6 & 0.6 \\
\hline \multicolumn{6}{|l|}{ United Kingdom } \\
\hline \multicolumn{6}{|l|}{ Linked } \\
\hline Real GDP & 0.2 & 0.2 & 0.0 & -0.1 & -0.1 \\
\hline Inflation & 0.4 & 0.5 & 0.4 & 0.2 & 0.0 \\
\hline \multicolumn{6}{|l|}{ Unlinked } \\
\hline Real GDP & 0.2 & 0.2 & 0.0 & -0.1 & -0.1 \\
\hline Inflation & 0.4 & 0.4 & 0.4 & 0.1 & 0.0 \\
\hline \multicolumn{6}{|l|}{ Canada } \\
\hline \multicolumn{6}{|l|}{ Linked } \\
\hline Real GDP & 0.5 & 0.4 & 0.2 & 0.0 & -0.2 \\
\hline Inflation & 0.1 & 0.3 & 0.4 & 0.4 & 0.3 \\
\hline \multicolumn{6}{|l|}{ Unlinked } \\
\hline Real GDP & 0.5 & 0.3 & 0.2 & 0.0 & -0.2 \\
\hline Inflation & 0.1 & 0.3 & 0.4 & 0.3 & 0.2 \\
\hline
\end{tabular}

Note: Nominal exchange rates are assumed fixed. Real interest rates and real government investment are unchanged. 
22. A personal income tax cut (Tables A4-A6) has a slightly lower initial effect on GDP, inflation and the current account than a corresponding government spending shock. Hence, a 1 per cent of GDP tax cut raises GDP by $1 / 2-1$ per cent compared with the 1-13/4 GDP effect following a government spending shock of similar magnitude. ${ }^{16}$ This is basically because part of a tax cut is saved rather than consumed, hence reducing the initial effect on domestic demand. Otherwise, the adjustment mechanisms are rather similar to those described above and the medium-term outcome is almost the same as in a government spending shock: the initial increase in consumption is gradually reduced by higher inflation and is eventually crowded out by lower net exports.

\section{2b) Nominal interest rate shocks}

23. A permanent reduction of short- and long-term nominal interest rates boost investment and consumption directly: consumption via positive cost of borrowing and wealth effects, investment via the user costs of capital. The increase in output kicks off a further increase in investment (through the accelerator), while consumption benefits from higher disposable income due to higher output and lower unemployment. The government accounts improves due to the increased economic activity as well as the lower debt servicing costs (for countries with net government debt). As unemployment falls below the equilibrium rate and demand pressures increase, wages and inflation picks up. With unchanged nominal exchange rates (Tables A7-A9), higher inflation crowds out both exports and private consumption. While inflation and unemployment returns to their baseline levels in the long run, the level of GDP is permanently a bit higher since the real interest rate is permanently lower and the capital stock larger. ${ }^{17}$ Effectively, the interest rate shock hence replaces consumption and exports by investment, stimulating the capital stock and hence potential output. The peak effects on output from a 1 percentage point nominal interest rate reduction range from $1 / 2$ per cent in the United States and the euro area to $3 / 4$ per cent in Japan. Inflation is up by $1 / 4-1 / 2$ percentage points after five years.

24. An example of the adjustment to an interest rate reduction assuming floating exchange rates is shown in Tables A10-A12. ${ }^{18}$ The reduction of interest rates now implies larger short-term effects on output since it triggers a currency depreciation, which in turn stimulates exports. The inflation response is also more significant than under fixed nominal exchange rates due to higher imported inflation and stronger demand pressure, implying that private consumption is reduced more substantially. Nonetheless, the shortto medium-term response of output to a change in interest rates is now up to 50 per cent higher than under fixed nominal exchange rates. Output increased by $3 / 4-1$ per cent across the major regions and inflation is up by $1 / 2-1$ percentage points following an interest rate reduction of 1 percentage point.

16. It should be emphasised that the model simulations do not incorporate potential beneficial supply-side effects from a tax cut as compared with a spending increase.

17. The notion of a permanently lower real interest rate is for illustrative purposes only: in a global financial market, financial flows will tend to equilibrate real returns to investment across countries. Hence, long-term real interest rates cannot be permanently influenced by monetary policy in any individual country.

18. The specification of exchange rate reactions used in INTERLINK is essentially an ad hoc feature, which can easily be modified for various purposes. The example in the present paper is based on a formulation with the exchange rate being determined in a rather ad hoc fashion by a combination of the differential vis-à-vis trading partners of price levels and short-term interest rate changes. A 1 percentage point interest rate reduction shock implies for all three major regions that the real effective exchange rate depreciates by around 5-6 per cent in the first year following the shock before returning to its baseline value after around three years. 
25. It is noted that the effects in other regions from an interest rate shock are to a large extent determined by the assumption on exchange rates. Under fixed nominal exchange rates, other regions benefit from larger export markets as well as gaining market shares, while only the former applies under floating rates. Hence, a 1 percentage point lowering of interest rates in the United States implies an output gain in the euro area and Japan of above $1 / 4$ per cent after two years under fixed exchange rates, while under floating exchange rates, the impact in these regions is almost neutral. ${ }^{19}$ Comparing the results of an interest rate cut across the three major regions, it appears that interest rate changes play a larger role in the model for Japan, but in practice the results are more a reflection of the strong sensitivity of exports to changes in competitiveness.

\section{2c) Exchange rate shocks}

26. The impact effect of a permanent nominal exchange rate depreciation (Tables A13-A19) is an increase of competitiveness, implying that export volumes are increased and import volumes reduced. The ensuing rise in output is dampened slightly by higher inflation (following lower unemployment and the weaker exchange rate). Overall, the effect of a 10 per cent effective depreciation (for given real interest rates) is to increase real GDP by $1 / 2-1 \frac{1}{2}$ per cent in the short to medium term, depending mainly on the sensitivity of net exports to changes in competitiveness (smallest effect in the United States, largest effect in Japan). As inflation goes up, competitiveness is gradually eroded and the economies return to their baseline levels of output, employment and inflation, with price levels being permanently higher. The initial gain in competitiveness implies an improvement of the current account which is sustained a long time after output has returned to its baseline. Other regions will experience a decline in net exports due to worsened competitiveness and hence a deterioration of their current accounts. Inflation will slow down in these regions as the nominal exchange rates appreciate in effective terms.

27. The ìncrease in inflation following a nominal exchange rate depreciation is substantially lowered if real side-effects are excluded (i.e. holding real GDP constant in all regions). While the impact is rather similar, the effects after 3-5 years differ substantially: with constant real GDP, annual inflation is up by less than $1 / 2$ percentage point in all three regions, compared with $1-1 \frac{1}{2}$ percentage points if real GDP and employment were to increase following a depreciation.

\section{2d) Oil and commodity price shocks}

28. An oil price increase ${ }^{20}$ mainly works its way through the system as a terms of trade shock (Table A20). For net oil importing countries there is an initial loss in real disposable incomes as prices of oil- and energy-related goods and services increase. This simultaneously leads to lower output and higher inflation (i.e. a negative supply shock). The degree of the downturn in demand depends partly on the extent to which consumption responds to lower disposable incomes and higher inflation and investment to lower output. A further effect arises from the net export side, since market growth slows and competitiveness

19. This result evidently hinges on the assumed reaction in exchange rates to the interest rate reduction. To the extent the US rate reduction triggers a larger and more sustained depreciation of the dollar, the euro area and Japan may well suffer output losses. In contrast, effects of an across-the-board global reduction of nominal interest rates will have beneficial effects for each region over and above domestic rate reductions only. This is because direct demand spillovers are more positive whilst exchange rate responses are likely to be neutral. INTERLINK simulations suggest that the additional positive effects from a global interest rate cut could increase the output responses by 50 per cent or more in the short term, compared to idiosyncratic country shocks.

20. This shock implicitly also includes price increases of other types of energy. 
changes (positively if inflation increases by less than among trading partners, otherwise negatively). Second-round effects depend on the response of wages to higher consumer prices. To the extent most wage earners are willing to accept a decline in real wages, unemployment will only increase modestly and inflation will soon be back to around its initial level. ${ }^{21}$ If wage earners demand compensation in terms of higher nominal wages an inflationary spiral is kicked off which can lead to a more protracted period of high inflation and lower growth. In the medium term, the initial output loss is recuperated as exports to oilproducers gradually picks up.

29. While the initial inflation effects of an oil price shock are fairly similar across the three major regions, the first-year output loss is a little smaller in the United States than in the euro area and Japan. Hence, for a 50 per cent increase in oil prices (corresponding to a $\$ 12 \frac{1}{2}$ rise if the oil price is $\$ 25$ per barrel), the initial output loss would be around $1 / 2$ per cent in the euro area and Japan, but closer to $1 / 4$ per cent in the United States. This is mainly because the terms-of-trade loss for the United States is smaller than those of the euro area and Japan (since the United States is a substantial oil producer, its net oil import is smaller in per cent of GDP than those of the euro area and Japan, even though the intensity of oil in production is much higher than elsewhere). Second-order inflation effects are slightly larger in the euro area than in the other major regions. Oil net-exporters like Canada would experience an output gain as real incomes start to increase.

30. A non-oil commodity price shock (Table A21) works basically in the same way as an oil price shock, i.e. as a supply shock, and the adjustment mechanisms are similar to the ones described above. If non-oil commodity prices were increased by 20 per cent, there would be a small decline in output (less than $1 / 4$ per cent in all three major regions) and inflation would go up slightly across the major regions. Again, Canada is an exception, being a large commodity producer.

21. The isolated effect on inflation of the oil price increase is a one-off increase followed by an almost immediate reversal to the baseline inflation rate. Hence, inflation is unaffected in the medium to long term, everything else being equal, but the price level is permanently higher. 


\section{BIBLIOGRAPHY}

GIORNO, C., P. RICHARDSON and W. SUYKER (1995),

"Technical progress, factor productivity and macroeconomic performance in the medium term", OECD Economics Department Working Papers, No. 157.

HALL, S.G. and J.D. WHITLEY (1999),

"Linkages between countries in international models", unpublished memo.

MURATA, K., D. TURNER, D. RAE and L. LE FOULER (2000),

"Modelling manufacturing export volumes equations: a system estimation approach", $O E C D$

Economics Department Working Papers, No. 235.

RAE, D. and D. TURNER (2001),

"A small global forecasting model", OECD Economics Department Working Papers, No. 286.

RICHARDSON, P. (1988),

"The structure and simulation properties of OECD's INTERLINK model", OECD Economic Studies, No. 10, Spring.

RICHARDSON, P., L. BOONE, C. GIORNO, M. MEACCI, D. RAE and D. TURNER (2000), "The concept, policy use and measurement of structural unemployment: estimating a time varying NAIRU across 21 OECD countries", OECD Economics Department Working Papers. No. 250.

TURNER, D., P. RICHARDSON and S. RAUFFET (1996),

"Modelling the supply side of seven major OECD economies", OECD Economics Department Working Papers, No. 167. 


\section{Annex. Standard Shocks}

Table A1. Government Spending Increase, United States

Table A2. Government Spending Increase, Japan

Table A3. Government Spending Increase, Euro Area

Table A4. Tax Cut, United States

Table A5. Tax Cut, Japan

Table A6. Tax Cut, Euro Area

Table A7. Interest Rate Cut, United States, Fixed Exchange Rate

Table A8. Interest Rate Cut, Japan, Fixed Exchange Rate

Table A9. Interest Rate Cut, Euro Area, Fixed Exchange Rate

Table A10. Interest Rate Cut, United States, Floating Exchange Rate

Table A11. Interest Rate Cut, Japan, Floating Exchange Rate

Table A12. Interest Rate Cut, Euro Area, Floating Exchange Rate

Table A13. Ten per cent US Dollar Depreciation

Table A14. Ten per cent US Dollar Depreciation (with fixed real output)

Table A15. Ten per cent Yen Depreciation

Table A16. Ten per cent Yen Depreciation (with fixed real output)

Table A17. Ten per cent Euro Depreciation

Table A18. Ten per cent Euro Depreciation (with fixed real output)

Table A19. Ten per cent Nominal Effective Depreciation

Table A20. Oil Price Increase

Table A21. Commodity Price Increase 
Table A1. Government Spending Increase, United States

(1 pp rise in Government non-wage consumption)

Deviations from baseline, in percent

\begin{tabular}{|c|c|c|c|c|c|}
\hline \multirow{3}{*}{ United States } & \multicolumn{5}{|c|}{ Years after shock } \\
\hline & \multirow[t]{2}{*}{1} & \multirow[t]{2}{*}{2} & \multirow[t]{2}{*}{3} & \multirow[t]{2}{*}{4} & 5 \\
\hline & & & & & \\
\hline GDP Level & 1.1 & 1.0 & 0.5 & 0.2 & 0.1 \\
\hline Inflation (Consumer Prices) & 0.2 & 0.7 & 1.0 & 1.2 & 1.2 \\
\hline Current account (\% GDP) & -0.4 & -0.3 & -0.3 & -0.4 & -0.5 \\
\hline Govt net lending (\% GDP) & -0.7 & -0.7 & -0.8 & -1.0 & -1.1 \\
\hline \multicolumn{6}{|l|}{ Japan } \\
\hline GDP Level & 0.5 & 0.5 & 0.1 & 0.0 & 0.3 \\
\hline Inflation (Consumer Prices) & 0.1 & 0.5 & 0.2 & -0.1 & 0.1 \\
\hline Current account (\% GDP) & 0.2 & 0.3 & 0.4 & 0.4 & 0.4 \\
\hline Govt net lending (\% GDP) & 0.0 & -0.1 & -0.1 & -0.1 & -0.1 \\
\hline \multicolumn{6}{|l|}{ European Union } \\
\hline GDP Level & 0.3 & 0.3 & 0.1 & 0.1 & 0.1 \\
\hline Inflation (Consumer Prices) & 0.1 & 0.3 & 0.4 & 0.4 & 0.5 \\
\hline Current account (\% GDP) & 0.2 & 0.3 & 0.3 & 0.3 & 0.4 \\
\hline Govt net lending (\% GDP) & 0.1 & 0.1 & 0.0 & 0.0 & 0.0 \\
\hline \multicolumn{6}{|l|}{ Euro Area } \\
\hline GDP Level & 0.4 & 0.4 & 0.1 & 0.1 & 0.2 \\
\hline Inflation (Consumer Prices) & 0.0 & 0.2 & 0.3 & 0.4 & 0.5 \\
\hline Current account (\% GDP) & 0.2 & 0.3 & 0.2 & 0.2 & 0.3 \\
\hline Govt net lending (\% GDP) & 0.1 & 0.1 & 0.0 & 0.0 & 0.0 \\
\hline \multicolumn{6}{|l|}{ Total OECD } \\
\hline GDP Level & 0.7 & 0.6 & 0.3 & 0.1 & 0.2 \\
\hline Inflation (Consumer Prices) & 0.1 & 0.4 & 0.6 & 0.7 & 0.7 \\
\hline Current account (\% GDP) & -0.1 & 0.0 & 0.1 & 0.0 & 0.0 \\
\hline Govt net lending (\% GDP) & -0.2 & -0.2 & -0.3 & -0.4 & -0.4 \\
\hline \multicolumn{6}{|l|}{ GDP Levels } \\
\hline Canada & 1.0 & 0.7 & 0.4 & 0.2 & 0.1 \\
\hline France & 0.2 & 0.3 & 0.2 & 0.1 & 0.1 \\
\hline Germany & 0.6 & 0.4 & 0.0 & 0.0 & 0.1 \\
\hline Italy & 0.3 & 0.4 & 0.1 & 0.0 & 0.1 \\
\hline United Kingdom & 0.2 & 0.3 & 0.1 & 0.0 & 0.0 \\
\hline \multicolumn{6}{|l|}{ Inflation (Consumer prices) } \\
\hline Canada & 0.0 & 0.7 & 1.0 & 1.0 & 1.0 \\
\hline France & 0.0 & 0.2 & 0.3 & 0.4 & 0.4 \\
\hline Germany & 0.0 & 0.1 & 0.3 & 0.4 & 0.5 \\
\hline Italy & 0.1 & 0.4 & 0.3 & 0.4 & 0.5 \\
\hline United Kingdom & 0.1 & 0.5 & 0.5 & 0.4 & 0.5 \\
\hline \multicolumn{6}{|l|}{ Nominal exchange rates are fixed } \\
\hline
\end{tabular}


Table A2. Government Spending Increase, Japan

(1 pp rise in Government non-wage consumption)

Deviations from baseline, in percent

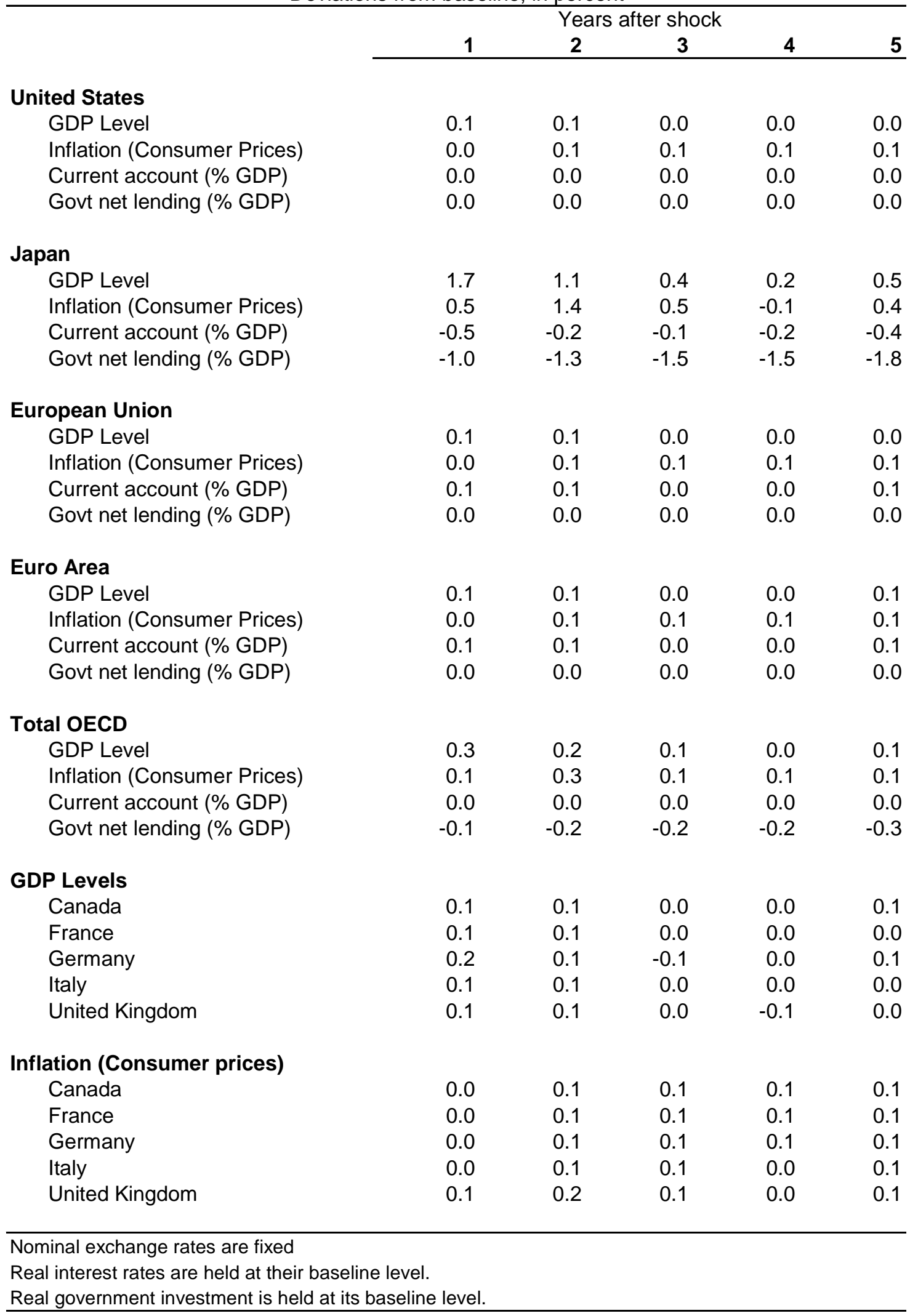


Table A3. Government Spending Increase, Euro Area

(1 pp rise in Government non-wage consumption)

Deviations from baseline, in percent

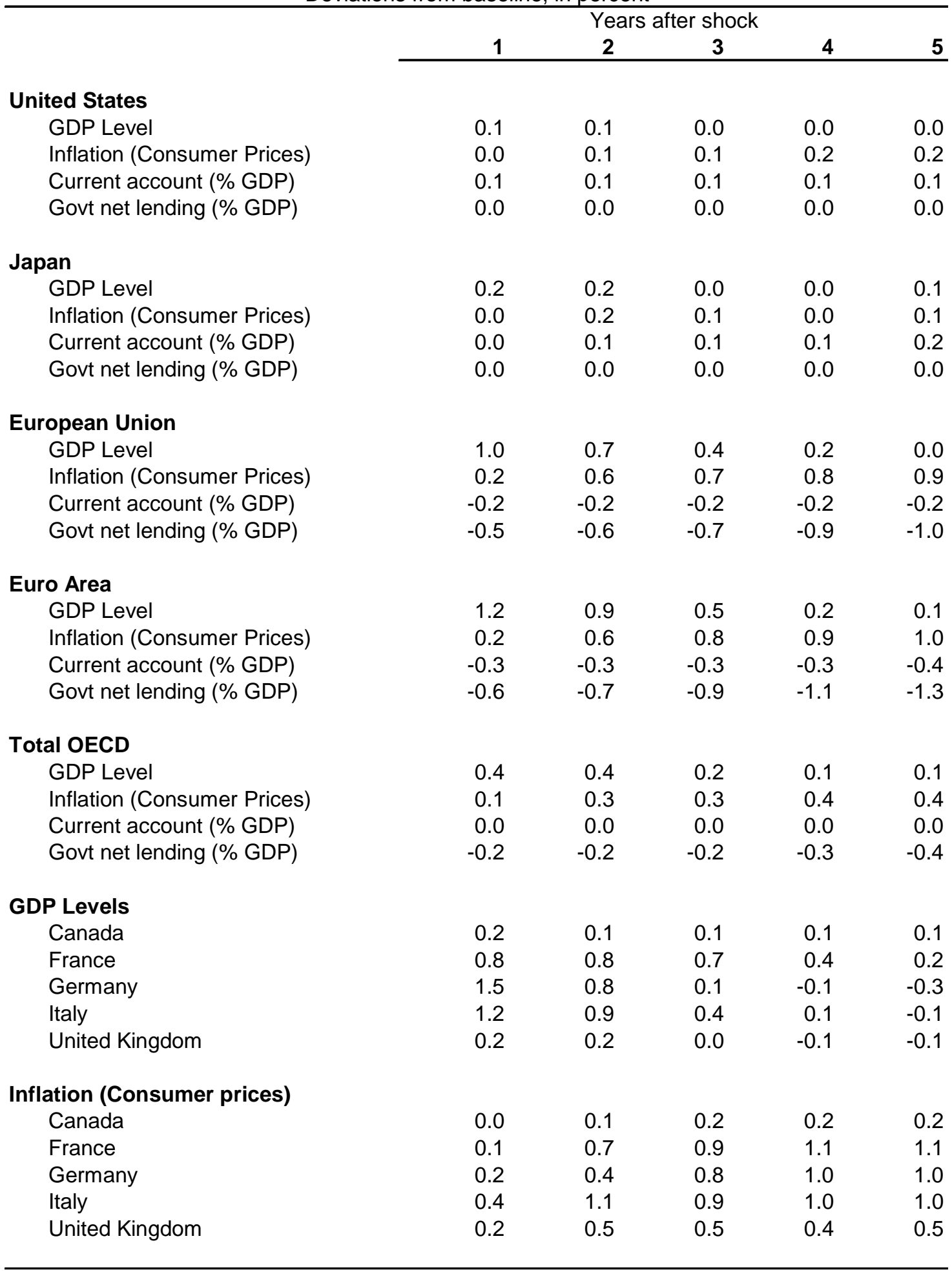

Nominal exchange rates are fixed

Real interest rates are held at their baseline level.

Real government investment is held at its baseline level. 
Table A4. Tax Cut, United States

(Drop in wage and salary tax rate of 1 percent of GDP)

Deviations from baseline, in percent

\begin{tabular}{|c|c|c|c|c|c|}
\hline \multirow{3}{*}{ United States } & \multicolumn{4}{|c|}{ Years after shock } & \multirow[b]{2}{*}{5} \\
\hline & \multirow[t]{2}{*}{1} & \multirow[t]{2}{*}{2} & \multirow[t]{2}{*}{3} & \multirow[t]{2}{*}{4} & \\
\hline & & & & & \\
\hline GDP Level & 0.4 & 0.8 & 0.8 & 0.6 & 0.4 \\
\hline Inflation (Consumer Prices) & 0.1 & 0.3 & 0.7 & 1.0 & 1.2 \\
\hline Current account (\% GDP) & -0.2 & -0.3 & -0.3 & -0.4 & -0.5 \\
\hline Govt net lending (\% GDP) & -0.9 & -0.8 & -0.8 & -0.9 & -1.1 \\
\hline \multicolumn{6}{|l|}{ Japan } \\
\hline GDP Level & 0.2 & 0.4 & 0.4 & 0.2 & 0.2 \\
\hline Inflation (Consumer Prices) & 0.0 & 0.3 & 0.3 & 0.2 & 0.1 \\
\hline Current account (\% GDP) & 0.1 & 0.2 & 0.3 & 0.4 & 0.5 \\
\hline Govt net lending (\% GDP) & 0.0 & 0.0 & 0.0 & -0.1 & -0.1 \\
\hline \multicolumn{6}{|l|}{ European Union } \\
\hline GDP Level & 0.1 & 0.3 & 0.3 & 0.2 & 0.2 \\
\hline Inflation (Consumer Prices) & 0.0 & 0.1 & 0.3 & 0.4 & 0.5 \\
\hline Current account (\% GDP) & 0.1 & 0.2 & 0.3 & 0.4 & 0.4 \\
\hline Govt net lending (\% GDP) & 0.0 & 0.1 & 0.1 & 0.1 & 0.0 \\
\hline \multicolumn{6}{|l|}{ Euro Area } \\
\hline GDP Level & 0.1 & 0.3 & 0.3 & 0.2 & 0.2 \\
\hline Inflation (Consumer Prices) & 0.0 & 0.1 & 0.2 & 0.4 & 0.5 \\
\hline Current account (\% GDP) & 0.1 & 0.2 & 0.3 & 0.3 & 0.3 \\
\hline Govt net lending (\% GDP) & 0.0 & 0.1 & 0.1 & 0.1 & 0.0 \\
\hline \multicolumn{6}{|l|}{ Total OECD } \\
\hline GDP Level & 0.3 & 0.5 & 0.5 & 0.4 & 0.3 \\
\hline Inflation (Consumer Prices) & 0.0 & 0.2 & 0.4 & 0.6 & 0.7 \\
\hline Current account (\% GDP) & 0.0 & 0.0 & 0.0 & 0.0 & 0.0 \\
\hline Govt net lending (\% GDP) & -0.3 & -0.3 & -0.3 & -0.3 & -0.4 \\
\hline \multicolumn{6}{|l|}{ GDP Levels } \\
\hline Canada & 0.4 & 0.7 & 0.7 & 0.5 & 0.3 \\
\hline France & 0.1 & 0.2 & 0.3 & 0.2 & 0.2 \\
\hline Germany & 0.2 & 0.4 & 0.3 & 0.2 & 0.1 \\
\hline Italy & 0.1 & 0.3 & 0.3 & 0.2 & 0.1 \\
\hline United Kingdom & 0.1 & 0.2 & 0.2 & 0.1 & 0.0 \\
\hline \multicolumn{6}{|l|}{ Inflation (Consumer prices) } \\
\hline Canada & 0.0 & 0.3 & 0.7 & 0.9 & 1.1 \\
\hline France & 0.0 & 0.1 & 0.2 & 0.3 & 0.4 \\
\hline Germany & 0.0 & 0.1 & 0.2 & 0.4 & 0.5 \\
\hline Italy & 0.0 & 0.2 & 0.3 & 0.4 & 0.5 \\
\hline United Kingdom & 0.0 & 0.2 & 0.4 & 0.5 & 0.6 \\
\hline \multicolumn{6}{|l|}{ Nominal exchange rates are fixed } \\
\hline $\begin{array}{l}\text { al interest rates are held at their } \\
\text { al government spending and inve }\end{array}$ & & & & & \\
\hline
\end{tabular}


Table A6. Tax Cut, Euro Area

(Drop in wage and salary tax rate of 1 percent of GDP)

Deviations from baseline, in percent

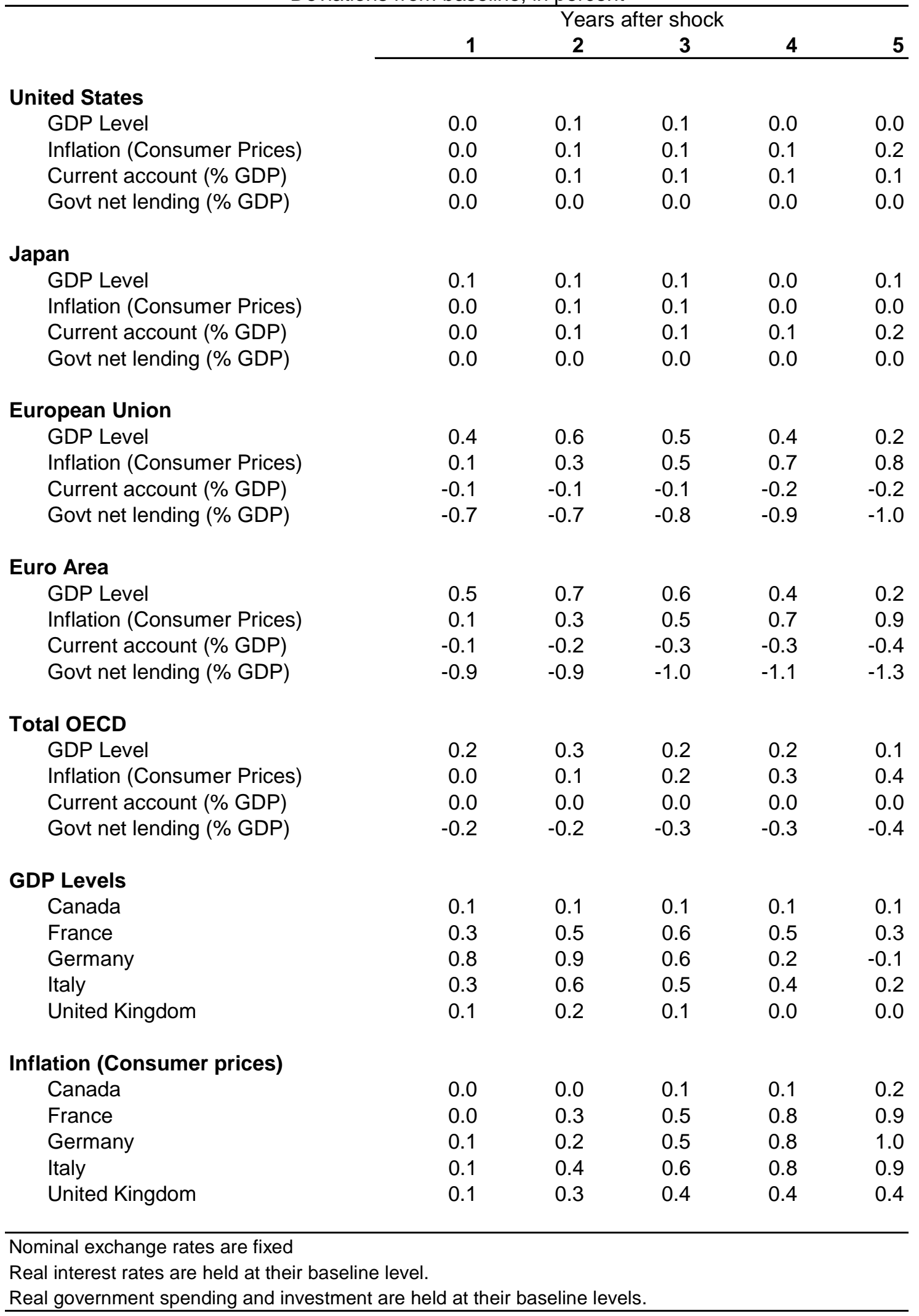


Table A7. Interest Rate Cut, United States, Fixed Exchange Rate

(Drop in short term and long term interest rates of 1 percentage point)

Deviations from baseline, in percent

\begin{tabular}{|c|c|c|c|c|c|}
\hline & & Yea & er she & & \\
\hline & 1 & 2 & 3 & 4 & 5 \\
\hline United States & & & & & \\
\hline GDP Level & 0.3 & 0.5 & 0.4 & 0.3 & 0.2 \\
\hline Inflation (Consumer Prices) & 0.0 & 0.2 & 0.4 & 0.5 & 0.4 \\
\hline Current account (\% GDP) & -0.1 & -0.1 & 0.0 & 0.1 & 0.1 \\
\hline Govt net lending (\% GDP) & 0.2 & 0.3 & 0.2 & 0.1 & 0.1 \\
\hline Japan & & & & & \\
\hline GDP Level & 0.2 & 0.3 & 0.3 & 0.2 & 0.2 \\
\hline Inflation (Consumer Prices) & 0.0 & 0.2 & 0.3 & 0.2 & 0.1 \\
\hline Current account (\% GDP) & 0.1 & 0.2 & 0.2 & 0.2 & 0.2 \\
\hline Govt net lending (\% GDP) & 0.0 & 0.1 & 0.1 & 0.1 & 0.1 \\
\hline European Union & & & & & \\
\hline GDP Level & 0.1 & 0.3 & 0.3 & 0.3 & 0.3 \\
\hline Inflation (Consumer Prices) & 0.0 & 0.1 & 0.2 & 0.3 & 0.3 \\
\hline Current account ( $\%$ GDP) & 0.0 & 0.1 & 0.1 & 0.1 & 0.1 \\
\hline Govt net lending (\% GDP) & 0.0 & 0.1 & 0.1 & 0.2 & 0.2 \\
\hline Euro Area & & & & & \\
\hline GDP Level & 0.1 & 0.3 & 0.3 & 0.3 & 0.3 \\
\hline Inflation (Consumer Prices) & 0.0 & 0.1 & 0.2 & 0.3 & 0.3 \\
\hline Current account (\% GDP) & 0.0 & 0.2 & 0.2 & 0.2 & 0.2 \\
\hline Govt net lending (\% GDP) & 0.0 & 0.1 & 0.1 & 0.2 & 0.2 \\
\hline Total OECD & & & & & \\
\hline GDP Level & 0.2 & 0.4 & 0.3 & 0.3 & 0.2 \\
\hline Inflation (Consumer Prices) & 0.0 & 0.1 & 0.3 & 0.3 & 0.4 \\
\hline Current account (\% GDP) & 0.0 & 0.0 & 0.1 & 0.1 & 0.1 \\
\hline Govt net lending (\% GDP) & 0.1 & 0.1 & 0.2 & 0.1 & 0.1 \\
\hline GDP Levels & & & & & \\
\hline Canada & 0.3 & 0.5 & 0.4 & 0.3 & 0.2 \\
\hline France & 0.1 & 0.2 & 0.2 & 0.2 & 0.3 \\
\hline Germany & 0.2 & 0.4 & 0.4 & 0.3 & 0.3 \\
\hline Italy & 0.1 & 0.3 & 0.3 & 0.3 & 0.2 \\
\hline United Kingdom & 0.1 & 0.2 & 0.2 & 0.1 & 0.1 \\
\hline Inflation (Consumer prices) & & & & & \\
\hline Canada & 0.0 & 0.2 & 0.4 & 0.5 & 0.5 \\
\hline France & 0.0 & 0.1 & 0.2 & 0.3 & 0.3 \\
\hline Germany & 0.0 & 0.1 & 0.2 & 0.3 & 0.4 \\
\hline Italy & 0.0 & 0.2 & 0.3 & 0.3 & 0.3 \\
\hline United Kingdom & 0.0 & 0.2 & 0.3 & 0.3 & 0.3 \\
\hline
\end{tabular}

Nominal exchange rates are fixed

Nominal interest rates are held at their baseline level for other countries.

Real government spending and investment are held at their baseline levels. 
Table A8. Interest Rate Cut, Japan, Fixed Exchange Rate

(Drop in short term and long term interest rates of 1 percentage point)

Deviations from baseline, in percent

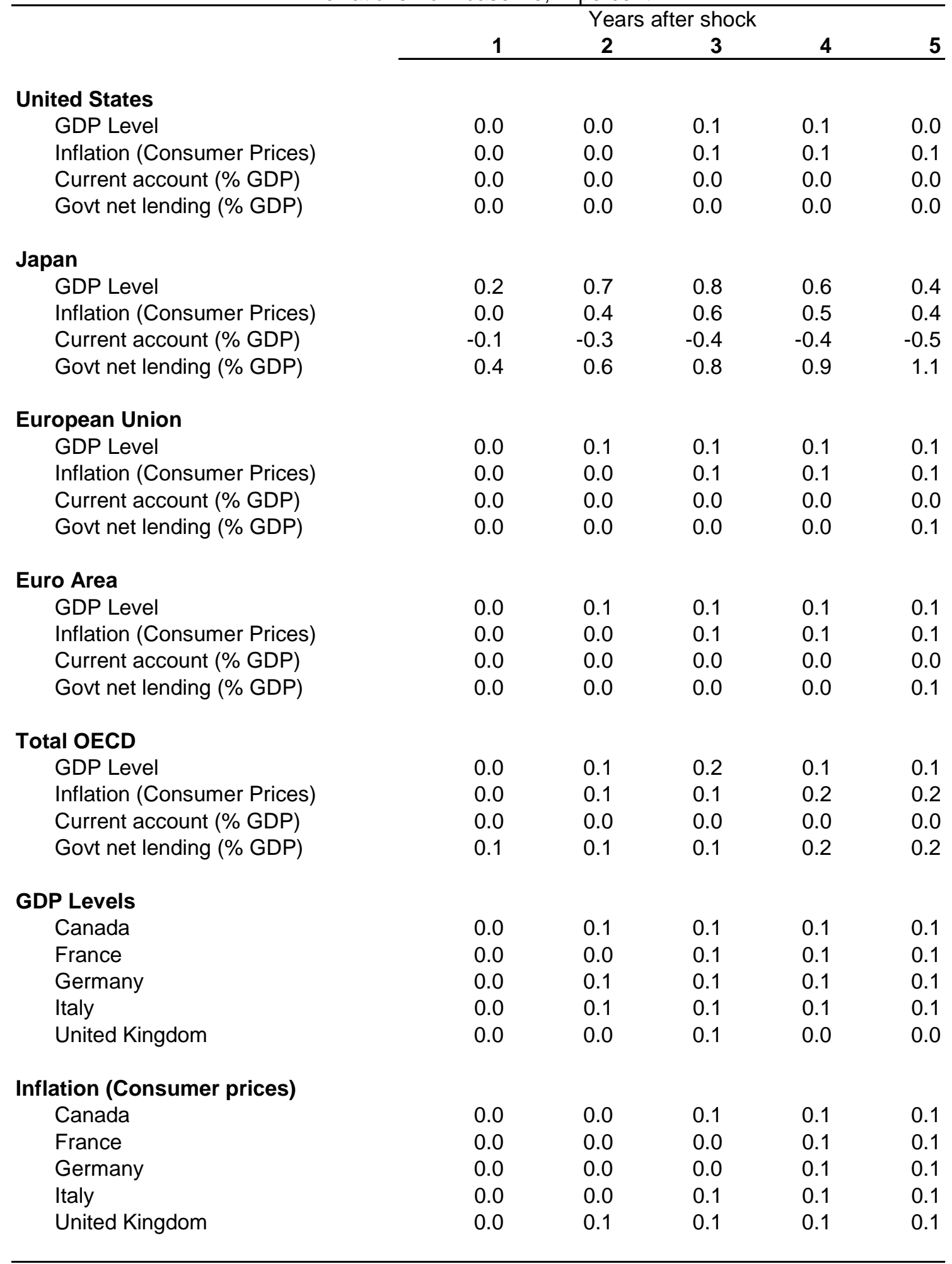

Nominal exchange rates are fixed

Nominal interest rates are held at their baseline level for other countries.

Real government spending and investment are held at their baseline levels. 
Table A9. Interest Rate Cut, Euro Area, Fixed Exchange Rate

(Drop in short term and long term interest rates of 1 percentage point)

Deviations from baseline, in percent

\begin{tabular}{|c|c|c|c|c|c|}
\hline \multirow{3}{*}{ United States } & \multicolumn{4}{|c|}{ Years after shock } & \multirow[b]{2}{*}{5} \\
\hline & \multirow[t]{2}{*}{1} & \multirow[t]{2}{*}{2} & \multirow[t]{2}{*}{3} & \multirow[t]{2}{*}{4} & \\
\hline & & & & & \\
\hline GDP Level & 0.0 & 0.1 & 0.1 & 0.1 & 0.1 \\
\hline Inflation (Consumer Prices) & 0.0 & 0.0 & 0.1 & 0.1 & 0.2 \\
\hline Current account (\% GDP) & 0.0 & 0.0 & 0.0 & 0.0 & 0.0 \\
\hline Govt net lending (\% GDP) & 0.0 & 0.0 & 0.0 & 0.0 & 0.0 \\
\hline \multicolumn{6}{|l|}{ Japan } \\
\hline GDP Level & 0.1 & 0.1 & 0.1 & 0.1 & 0.1 \\
\hline Inflation (Consumer Prices) & 0.0 & 0.1 & 0.1 & 0.1 & 0.1 \\
\hline Current account (\% GDP) & 0.0 & 0.0 & 0.0 & 0.1 & 0.1 \\
\hline Govt net lending (\% GDP) & 0.0 & 0.0 & 0.0 & 0.0 & 0.0 \\
\hline \multicolumn{6}{|l|}{ European Union } \\
\hline GDP Level & 0.3 & 0.5 & 0.5 & 0.5 & 0.5 \\
\hline Inflation (Consumer Prices) & 0.1 & 0.1 & 0.2 & 0.2 & 0.2 \\
\hline Current account (\% GDP) & -0.1 & -0.2 & -0.2 & -0.2 & -0.3 \\
\hline Govt net lending (\% GDP) & 0.3 & 0.5 & 0.6 & 0.6 & 0.7 \\
\hline \multicolumn{6}{|l|}{ Euro Area } \\
\hline GDP Level & 0.4 & 0.6 & 0.6 & 0.6 & 0.6 \\
\hline Inflation (Consumer Prices) & 0.1 & 0.1 & 0.2 & 0.2 & 0.2 \\
\hline Current account (\% GDP) & -0.1 & -0.2 & -0.2 & -0.3 & -0.3 \\
\hline Govt net lending (\% GDP) & 0.3 & 0.5 & 0.7 & 0.7 & 0.8 \\
\hline \multicolumn{6}{|l|}{ Total OECD } \\
\hline GDP Level & 0.1 & 0.3 & 0.3 & 0.3 & 0.2 \\
\hline Inflation (Consumer Prices) & 0.0 & 0.1 & 0.1 & 0.2 & 0.2 \\
\hline Current account (\% GDP) & 0.0 & 0.0 & 0.0 & 0.0 & -0.1 \\
\hline Govt net lending (\% GDP) & 0.1 & 0.2 & 0.2 & 0.3 & 0.3 \\
\hline \multicolumn{6}{|l|}{ GDP Levels } \\
\hline Canada & 0.1 & 0.1 & 0.1 & 0.1 & 0.1 \\
\hline France & 0.1 & 0.3 & 0.5 & 0.5 & 0.6 \\
\hline Germany & 0.7 & 1.0 & 0.8 & 0.6 & 0.5 \\
\hline Italy & 0.3 & 0.5 & 0.5 & 0.6 & 0.7 \\
\hline United Kingdom & 0.1 & 0.2 & 0.2 & 0.1 & 0.1 \\
\hline \multicolumn{6}{|l|}{ Inflation (Consumer prices) } \\
\hline Canada & 0.0 & 0.0 & 0.1 & 0.1 & 0.2 \\
\hline France & 0.0 & 0.1 & 0.2 & 0.2 & 0.3 \\
\hline Germany & 0.1 & 0.2 & 0.3 & 0.5 & 0.5 \\
\hline Italy & 0.3 & 0.1 & 0.1 & 0.0 & -0.2 \\
\hline United Kingdom & 0.0 & 0.2 & 0.3 & 0.2 & 0.2 \\
\hline
\end{tabular}


Table A10. Interest Rate Cut, United States, Floating Exchange Rate

(Drop in short term and long term interest rates of 1 percentage point) Deviations from baseline, in percent

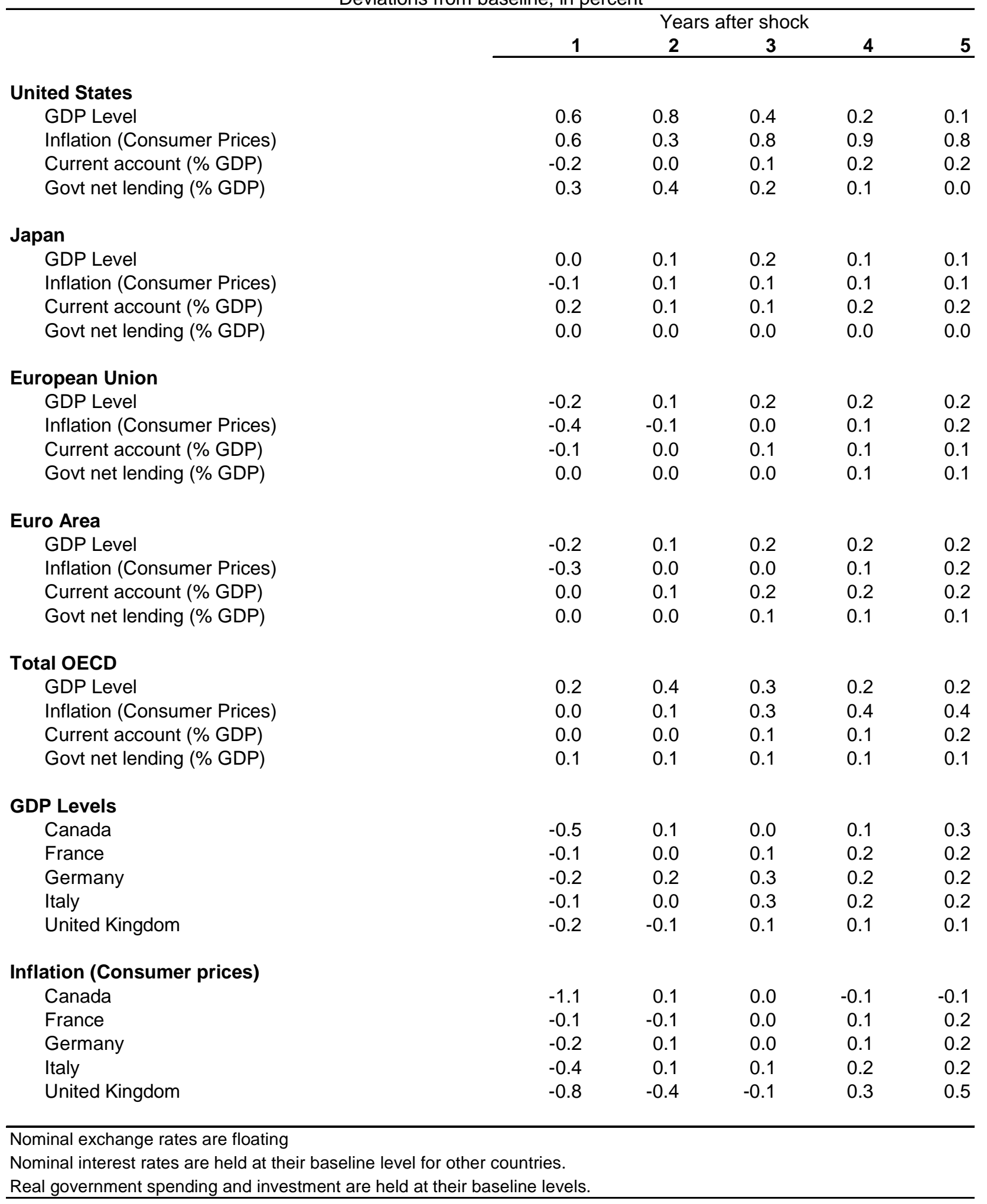


Table A11. Interest Rate Cut, Japan, Floating Exchange Rate

(Drop in short term and long term interest rates of 1 percentage point)

Deviations from baseline, in percent

\begin{tabular}{|c|c|c|c|c|c|}
\hline & & $\overline{Y e a}$ & er sho & & \\
\hline & 1 & 2 & 3 & 4 & 5 \\
\hline United States & & & & & \\
\hline GDP Level & -0.1 & 0.0 & 0.0 & 0.0 & 0.0 \\
\hline Inflation (Consumer Prices) & -0.2 & 0.0 & 0.0 & 0.0 & 0.0 \\
\hline Current account (\% GDP) & 0.0 & 0.0 & 0.0 & 0.0 & 0.0 \\
\hline Govt net lending (\% GDP) & 0.0 & 0.0 & 0.0 & 0.0 & 0.0 \\
\hline Japan & & & & & \\
\hline GDP Level & 0.4 & 0.9 & 0.7 & 0.4 & 0.4 \\
\hline Inflation (Consumer Prices) & 0.2 & 0.4 & 0.9 & 0.8 & 0.8 \\
\hline Current account (\% GDP) & -0.1 & 0.0 & -0.1 & -0.1 & -0.1 \\
\hline Govt net lending (\% GDP) & 0.3 & 0.5 & 0.7 & 0.8 & 0.9 \\
\hline European Union & & & & & \\
\hline GDP Level & -0.1 & 0.0 & 0.0 & 0.0 & 0.0 \\
\hline Inflation (Consumer Prices) & -0.1 & 0.0 & 0.0 & 0.0 & 0.0 \\
\hline Current account (\% GDP) & 0.0 & 0.0 & 0.0 & 0.0 & 0.0 \\
\hline Govt net lending (\% GDP) & 0.0 & 0.0 & 0.0 & 0.0 & 0.0 \\
\hline Euro Area & & & & & \\
\hline GDP Level & -0.1 & 0.0 & 0.0 & 0.0 & 0.0 \\
\hline Inflation (Consumer Prices) & -0.1 & 0.0 & 0.0 & 0.0 & 0.0 \\
\hline Current account ( $\%$ GDP) & 0.0 & 0.0 & 0.0 & 0.0 & 0.0 \\
\hline Govt net lending (\% GDP) & 0.0 & 0.0 & 0.0 & 0.0 & 0.0 \\
\hline Total OECD & & & & & \\
\hline GDP Level & 0.0 & 0.1 & 0.1 & 0.1 & 0.0 \\
\hline Inflation (Consumer Prices) & -0.1 & 0.0 & 0.1 & 0.1 & 0.1 \\
\hline Current account (\% GDP) & 0.0 & 0.0 & 0.0 & 0.0 & 0.0 \\
\hline Govt net lending (\% GDP) & 0.0 & 0.1 & 0.1 & 0.1 & 0.1 \\
\hline GDP Levels & & & & & \\
\hline Canada & 0.0 & -0.1 & 0.0 & 0.0 & 0.0 \\
\hline France & 0.0 & 0.0 & 0.0 & 0.0 & 0.0 \\
\hline Germany & -0.1 & 0.0 & 0.0 & 0.0 & 0.0 \\
\hline Italy & 0.0 & 0.0 & 0.0 & 0.0 & 0.0 \\
\hline United Kingdom & -0.1 & 0.0 & 0.0 & 0.0 & 0.0 \\
\hline Inflation (Consumer prices) & & & & & \\
\hline Canada & -0.1 & 0.0 & -0.1 & 0.0 & -0.1 \\
\hline France & -0.1 & 0.0 & 0.0 & 0.0 & 0.0 \\
\hline Germany & -0.1 & 0.0 & 0.0 & 0.0 & 0.0 \\
\hline Italy & -0.1 & 0.0 & 0.0 & 0.0 & 0.0 \\
\hline United Kingdom & -0.2 & -0.2 & -0.1 & 0.0 & 0.0 \\
\hline
\end{tabular}

Nominal exchange rates are floating

Nominal interest rates are held at their baseline level for other countries.

Real government spending and investment are held at their baseline levels. 
Table A12. Interest Rate Cut, Euro Area, Floating Exchange Rate

(Drop in short term and long term interest rates of 1 percentage point)

Deviations from baseline, in percent

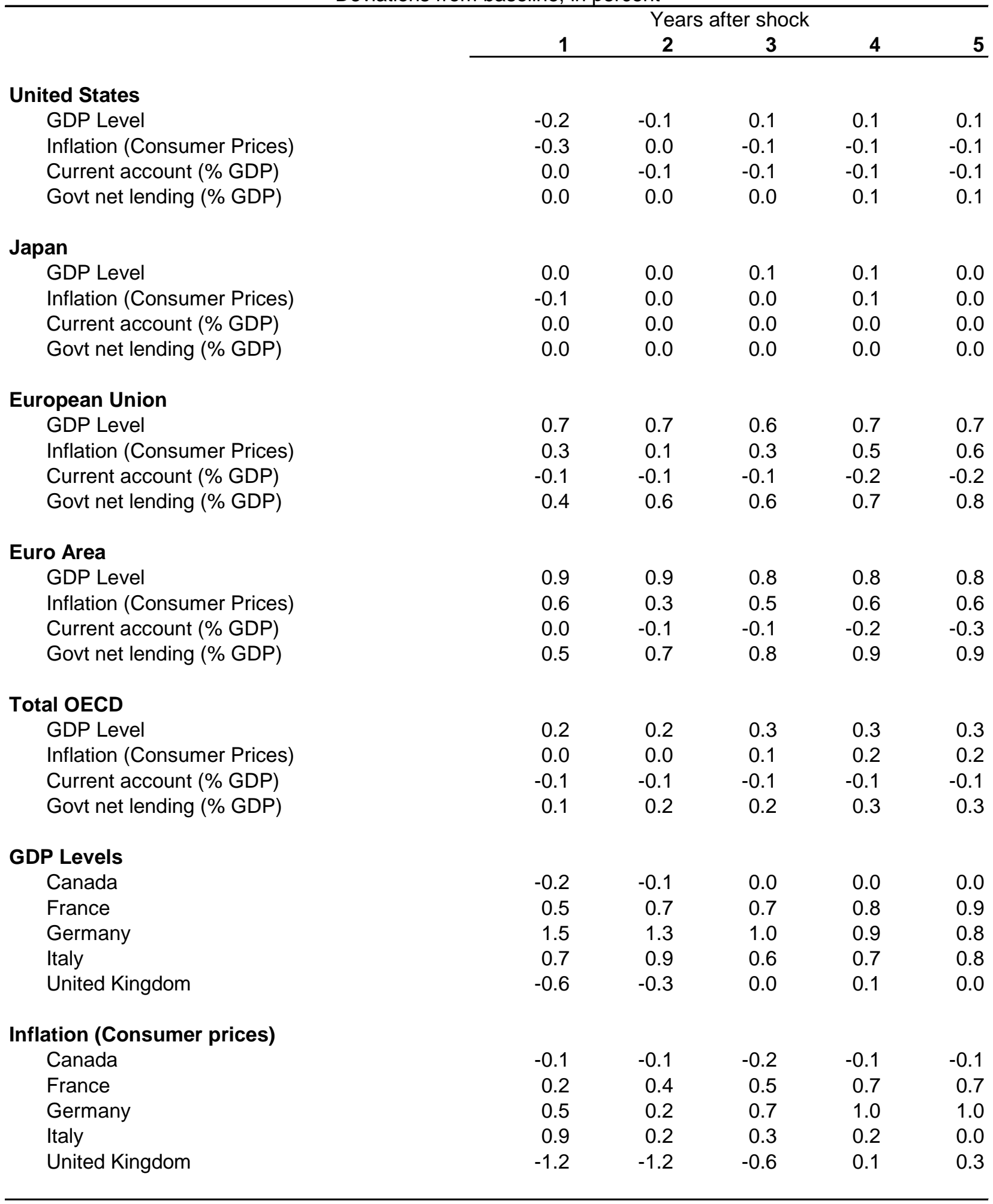

Nominal exchange rates are floating

Nominal interest rates are held at their baseline level for other countries.

Real government spending and investment are held at their baseline levels. 
Table A13. Ten percent US Dollar Depreciation

Deviations from baseline, in percent

\begin{tabular}{|c|c|c|c|c|c|}
\hline \multirow{3}{*}{ United States } & \multicolumn{5}{|c|}{ Years after shock } \\
\hline & \multirow[t]{2}{*}{1} & \multirow[t]{2}{*}{2} & \multirow[t]{2}{*}{3} & \multirow[t]{2}{*}{4} & 5 \\
\hline & & & & & \\
\hline GDP Level & 0.2 & 0.7 & 0.4 & 0.0 & -0.3 \\
\hline Inflation (Consumer Prices) & 1.0 & 0.6 & 0.9 & 1.1 & 1.1 \\
\hline Current account (\% GDP) & 0.0 & 0.2 & 0.3 & 0.4 & 0.4 \\
\hline Govt net lending (\% GDP) & -0.2 & 0.1 & 0.0 & 0.0 & -0.1 \\
\hline \multicolumn{6}{|l|}{ Japan } \\
\hline GDP Level & -0.2 & -0.5 & -0.4 & -0.4 & -0.5 \\
\hline Inflation (Consumer Prices) & -0.2 & -0.3 & -0.4 & -0.3 & -0.3 \\
\hline Current account (\% GDP) & 0.0 & -0.1 & -0.3 & -0.4 & -0.5 \\
\hline Govt net lending (\% GDP) & 0.0 & 0.0 & 0.0 & 0.0 & 0.0 \\
\hline \multicolumn{6}{|l|}{ European Union } \\
\hline GDP Level & -0.3 & -0.4 & -0.2 & -0.1 & 0.0 \\
\hline Inflation (Consumer Prices) & -0.5 & -0.4 & -0.5 & -0.6 & -0.6 \\
\hline Current account (\% GDP) & -0.1 & -0.2 & -0.3 & -0.3 & -0.3 \\
\hline Govt net lending (\% GDP) & 0.1 & 0.0 & 0.0 & 0.0 & 0.0 \\
\hline \multicolumn{6}{|l|}{ Euro Area } \\
\hline GDP Level & -0.3 & -0.4 & -0.3 & -0.2 & -0.1 \\
\hline Inflation (Consumer Prices) & -0.4 & -0.3 & -0.5 & -0.6 & -0.6 \\
\hline Current account (\% GDP) & -0.1 & -0.2 & -0.3 & -0.4 & -0.4 \\
\hline Govt net lending (\% GDP) & 0.1 & 0.0 & 0.0 & 0.0 & 0.1 \\
\hline \multicolumn{6}{|l|}{ Total OECD } \\
\hline GDP Level & -0.2 & -0.1 & -0.1 & -0.2 & -0.2 \\
\hline Inflation (Consumer Prices) & 0.0 & -0.1 & 0.0 & 0.0 & 0.0 \\
\hline Current account (\% GDP) & 0.1 & 0.0 & 0.0 & 0.0 & 0.0 \\
\hline Govt net lending (\% GDP) & 0.0 & 0.0 & 0.0 & -0.1 & -0.1 \\
\hline \multicolumn{6}{|l|}{ GDP Levels } \\
\hline Canada & -1.2 & -0.9 & -1.0 & -0.6 & 0.2 \\
\hline France & -0.2 & -0.4 & -0.3 & -0.3 & -0.2 \\
\hline Germany & -0.3 & -0.4 & -0.3 & -0.2 & -0.1 \\
\hline Italy & -0.2 & -0.4 & -0.2 & -0.2 & 0.0 \\
\hline United Kingdom & -0.3 & -0.2 & 0.1 & 0.2 & 0.2 \\
\hline \multicolumn{6}{|l|}{ Inflation (Consumer prices) } \\
\hline Canada & -1.7 & -1.0 & -1.1 & -1.3 & -1.3 \\
\hline France & -0.2 & -0.3 & -0.5 & -0.6 & -0.7 \\
\hline Germany & -0.3 & -0.1 & -0.4 & -0.5 & -0.7 \\
\hline Italy & -0.6 & -0.4 & -0.5 & -0.6 & -0.6 \\
\hline United Kingdom & -1.1 & -0.8 & -0.7 & -0.4 & -0.2 \\
\hline
\end{tabular}


Table A14. Ten percent US Dollar Depreciation

(holding GDPV at baseline level using CGV as instrument)

Deviations from baseline, in percent

\begin{tabular}{|c|c|c|c|c|c|}
\hline \multirow[t]{3}{*}{ 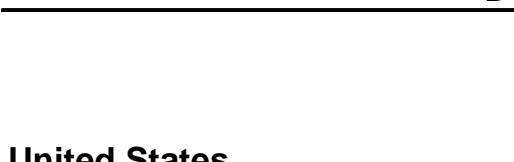 } & \multicolumn{5}{|c|}{ Years after shock } \\
\hline & 1 & 2 & 3 & 4 & 5 \\
\hline & \multicolumn{5}{|c|}{ United States } \\
\hline GDP Level & 0.0 & 0.0 & 0.0 & 0.0 & 0.0 \\
\hline Inflation (Consumer Prices) & 0.9 & 0.3 & 0.2 & 0.3 & 0.3 \\
\hline \multicolumn{6}{|l|}{ Japan } \\
\hline GDP Level & 0.0 & 0.0 & 0.0 & 0.0 & 0.0 \\
\hline Inflation (Consumer Prices) & -0.2 & 0.1 & 0.0 & 0.0 & 0.0 \\
\hline \multicolumn{6}{|l|}{ European Union } \\
\hline GDP Level & 0.0 & 0.0 & 0.0 & 0.0 & 0.0 \\
\hline Inflation (Consumer Prices) & -0.5 & -0.2 & -0.3 & -0.3 & -0.3 \\
\hline \multicolumn{6}{|l|}{ Euro Area } \\
\hline GDP Level & 0.0 & 0.0 & 0.0 & 0.0 & 0.0 \\
\hline Inflation (Consumer Prices) & -0.4 & -0.2 & -0.2 & -0.3 & -0.3 \\
\hline \multicolumn{6}{|l|}{ Total OECD } \\
\hline GDP Level & 0.0 & 0.0 & 0.0 & 0.0 & 0.0 \\
\hline Inflation (Consumer Prices) & 0.0 & 0.0 & -0.1 & -0.1 & 0.0 \\
\hline \multicolumn{6}{|l|}{ Inflation (Consumer prices) } \\
\hline Canada & -1.8 & -0.4 & -0.5 & -0.5 & -0.4 \\
\hline France & -0.1 & 0.0 & -0.1 & -0.1 & -0.2 \\
\hline Germany & -0.3 & 0.0 & -0.1 & -0.2 & -0.2 \\
\hline Italy & -0.5 & -0.1 & -0.2 & -0.2 & -0.3 \\
\hline United Kingdom & -0.9 & -0.4 & -0.5 & -0.4 & -0.3 \\
\hline
\end{tabular}


Table A15. Ten percent Yen Depreciation

Deviations from baseline, in percent

\begin{tabular}{|c|c|c|c|c|c|}
\hline \multirow{3}{*}{ United States } & \multicolumn{5}{|c|}{ Years after shock } \\
\hline & \multirow[t]{2}{*}{1} & \multirow[t]{2}{*}{2} & \multirow[t]{2}{*}{3} & \multirow[t]{2}{*}{4} & 5 \\
\hline & & & & & \\
\hline & 0.0 & -0.1 & -0.1 & 0.0 & 0.0 \\
\hline Inflation (Consumer Prices) & -0.2 & -0.1 & -0.1 & -0.2 & -0.2 \\
\hline Current account (\% GDP) & 0.0 & 0.0 & 0.0 & -0.1 & -0.1 \\
\hline Govt net lending (\% GDP) & 0.1 & 0.0 & 0.0 & 0.0 & 0.0 \\
\hline \multicolumn{6}{|l|}{ Japan } \\
\hline GDP Level & 0.6 & 1.3 & 1.1 & 0.8 & 0.8 \\
\hline Inflation (Consumer Prices) & 0.4 & 0.7 & 1.0 & 0.6 & 0.5 \\
\hline Current account (\% GDP) & 0.0 & 0.4 & 0.8 & 1.0 & 1.2 \\
\hline Govt net lending (\% GDP) & -0.1 & -0.1 & -0.2 & -0.2 & -0.3 \\
\hline \multicolumn{6}{|l|}{ European Union } \\
\hline GDP Level & 0.0 & 0.0 & -0.1 & -0.1 & -0.1 \\
\hline Inflation (Consumer Prices) & -0.1 & -0.1 & -0.1 & -0.2 & -0.2 \\
\hline Current account (\% GDP) & 0.0 & 0.0 & -0.1 & -0.1 & -0.2 \\
\hline Govt net lending (\% GDP) & 0.0 & 0.0 & 0.0 & 0.0 & 0.0 \\
\hline \multicolumn{6}{|l|}{ Euro Area } \\
\hline GDP Level & 0.0 & 0.0 & -0.1 & -0.1 & -0.1 \\
\hline Inflation (Consumer Prices) & -0.1 & -0.1 & -0.1 & -0.2 & -0.2 \\
\hline Current account (\% GDP) & 0.0 & 0.0 & -0.1 & -0.1 & -0.2 \\
\hline Govt net lending (\% GDP) & 0.0 & 0.0 & 0.0 & 0.0 & 0.0 \\
\hline \multicolumn{6}{|l|}{ Total OECD } \\
\hline GDP Level & 0.1 & 0.1 & 0.1 & 0.0 & 0.0 \\
\hline Inflation (Consumer Prices) & -0.1 & 0.0 & 0.0 & -0.1 & -0.1 \\
\hline Current account (\% GDP) & -0.1 & 0.0 & 0.0 & 0.0 & 0.0 \\
\hline Govt net lending (\% GDP) & 0.0 & 0.0 & 0.0 & 0.0 & 0.0 \\
\hline \multicolumn{6}{|l|}{ GDP Levels } \\
\hline Canada & 0.0 & -0.1 & -0.2 & -0.3 & -0.2 \\
\hline France & 0.0 & 0.0 & -0.1 & -0.1 & -0.1 \\
\hline Germany & 0.0 & 0.0 & -0.2 & -0.2 & -0.2 \\
\hline Italy & 0.0 & 0.0 & -0.1 & -0.1 & -0.1 \\
\hline United Kingdom & 0.0 & 0.0 & 0.0 & 0.0 & 0.0 \\
\hline \multicolumn{6}{|l|}{ Inflation (Consumer prices) } \\
\hline Canada & -0.1 & 0.0 & -0.1 & -0.2 & -0.3 \\
\hline France & -0.1 & 0.0 & -0.1 & -0.1 & -0.2 \\
\hline Germany & -0.1 & 0.0 & 0.0 & -0.1 & -0.2 \\
\hline Italy & -0.1 & -0.1 & -0.1 & -0.2 & -0.3 \\
\hline United Kingdom & -0.3 & -0.2 & -0.2 & -0.2 & -0.2 \\
\hline
\end{tabular}


Table A16. Ten percent Yen Depreciation

(holding GDPV at baseline level using CGV as instrument)

Deviations from baseline, in percent

\begin{tabular}{|c|c|c|c|c|c|}
\hline & \multicolumn{5}{|c|}{ Years after shock } \\
\hline & 1 & 2 & 3 & 4 & 5 \\
\hline \multicolumn{6}{|l|}{ United States } \\
\hline GDP Level & 0.0 & 0.0 & 0.0 & 0.0 & 0.0 \\
\hline Inflation (Consumer Prices) & -0.3 & -0.1 & -0.1 & -0.2 & -0.2 \\
\hline \multicolumn{6}{|l|}{ Japan } \\
\hline GDP Level & 0.0 & 0.0 & 0.0 & 0.0 & 0.0 \\
\hline Inflation (Consumer Prices) & 0.2 & -0.1 & 0.0 & 0.0 & 0.0 \\
\hline \multicolumn{6}{|l|}{ European Union } \\
\hline GDP Level & 0.0 & 0.0 & 0.0 & 0.0 & 0.0 \\
\hline Inflation (Consumer Prices) & -0.1 & -0.1 & -0.1 & -0.2 & -0.2 \\
\hline \multicolumn{6}{|l|}{ Euro Area } \\
\hline GDP Level & 0.0 & 0.0 & 0.0 & 0.0 & 0.0 \\
\hline Inflation (Consumer Prices) & -0.1 & -0.1 & -0.1 & -0.1 & -0.1 \\
\hline \multicolumn{6}{|l|}{ Total OECD } \\
\hline GDP Level & 0.0 & 0.0 & 0.0 & 0.0 & 0.0 \\
\hline Inflation (Consumer Prices) & -0.1 & -0.1 & -0.1 & -0.1 & -0.2 \\
\hline \multicolumn{6}{|l|}{ Inflation (Consumer prices) } \\
\hline Canada & -0.1 & 0.0 & 0.0 & -0.1 & -0.1 \\
\hline France & -0.1 & 0.0 & 0.0 & -0.1 & -0.1 \\
\hline Germany & -0.1 & 0.0 & -0.1 & -0.1 & -0.1 \\
\hline Italy & -0.1 & -0.1 & -0.1 & -0.1 & -0.2 \\
\hline United Kingdom & -0.3 & -0.2 & -0.3 & -0.3 & -0.3 \\
\hline
\end{tabular}


Table A17. Ten percent Euro Depreciation

(includes Denmark)

Deviations from baseline, in percent

\begin{tabular}{|c|c|c|c|c|c|}
\hline \multirow{3}{*}{ United States } & \multicolumn{4}{|c|}{ Years after shock } & \multirow[b]{2}{*}{5} \\
\hline & \multirow[t]{2}{*}{1} & \multirow[t]{2}{*}{2} & \multirow[t]{2}{*}{3} & \multirow[t]{2}{*}{4} & \\
\hline & & & & & \\
\hline GDP Level & -0.1 & -0.3 & -0.2 & -0.1 & 0.1 \\
\hline Inflation (Consumer Prices) & -0.3 & -0.3 & -0.4 & -0.5 & -0.5 \\
\hline Current account (\% GDP) & -0.1 & -0.1 & -0.2 & -0.2 & -0.2 \\
\hline Govt net lending (\% GDP) & 0.1 & 0.0 & 0.0 & 0.0 & 0.0 \\
\hline \multicolumn{6}{|l|}{ Japan } \\
\hline GDP Level & -0.2 & -0.4 & -0.5 & -0.3 & -0.3 \\
\hline Inflation (Consumer Prices) & -0.1 & -0.3 & -0.4 & -0.3 & -0.2 \\
\hline Current account (\% GDP) & 0.0 & -0.2 & -0.3 & -0.4 & -0.5 \\
\hline Govt net lending (\% GDP) & 0.0 & 0.0 & 0.1 & 0.1 & 0.1 \\
\hline \multicolumn{6}{|l|}{ European Union } \\
\hline GDP Level & 0.6 & 0.6 & 0.4 & 0.2 & 0.0 \\
\hline Inflation (Consumer Prices) & 0.4 & 0.4 & 0.7 & 0.9 & 1.0 \\
\hline Current account (\% GDP) & 0.1 & 0.3 & 0.4 & 0.5 & 0.5 \\
\hline Govt net lending (\% GDP) & 0.0 & 0.1 & 0.0 & -0.1 & -0.2 \\
\hline \multicolumn{6}{|l|}{ Euro Area } \\
\hline GDP Level & 0.8 & 0.9 & 0.5 & 0.2 & -0.1 \\
\hline Inflation (Consumer Prices) & 0.7 & 0.8 & 1.0 & 1.2 & 1.3 \\
\hline Current account (\% GDP) & 0.4 & 0.6 & 0.7 & 0.7 & 0.7 \\
\hline Govt net lending (\% GDP) & -0.1 & 0.1 & 0.0 & -0.1 & -0.2 \\
\hline \multicolumn{6}{|l|}{ Total OECD } \\
\hline GDP Level & 0.0 & 0.0 & -0.1 & 0.0 & 0.0 \\
\hline Inflation (Consumer Prices) & -0.1 & -0.1 & -0.1 & 0.0 & 0.0 \\
\hline Current account (\% GDP) & 0.0 & 0.0 & -0.1 & -0.1 & -0.1 \\
\hline Govt net lending (\% GDP) & 0.0 & 0.0 & 0.0 & -0.1 & -0.1 \\
\hline \multicolumn{6}{|l|}{ GDP Levels } \\
\hline Canada & -0.3 & -0.5 & -0.6 & -0.4 & -0.2 \\
\hline France & 0.6 & 0.8 & 0.6 & 0.4 & 0.2 \\
\hline Germany & 1.1 & 0.9 & 0.4 & 0.0 & -0.3 \\
\hline Italy & 0.5 & 0.9 & 0.5 & 0.1 & -0.2 \\
\hline United Kingdom & -0.7 & -0.5 & 0.1 & 0.5 & 0.6 \\
\hline \multicolumn{6}{|l|}{ Inflation (Consumer prices) } \\
\hline Canada & -0.1 & -0.1 & -0.4 & -0.6 & -0.7 \\
\hline France & 0.3 & 0.6 & 0.9 & 1.2 & 1.3 \\
\hline Germany & 0.6 & 0.3 & 0.8 & 1.2 & 1.4 \\
\hline Italy & 0.9 & 1.1 & 1.1 & 1.2 & 1.2 \\
\hline United Kingdom & -1.5 & -1.7 & -1.2 & -0.4 & 0.1 \\
\hline
\end{tabular}


Table A18. Ten percent Euro Depreciation (holding GDPV at baseline level using CGV as instrument)

Deviations from baseline, in percent

\begin{tabular}{|c|c|c|c|c|c|}
\hline \multirow{3}{*}{ United States } & \multicolumn{5}{|c|}{ Years after shock } \\
\hline & 1 & 2 & 3 & 4 & 5 \\
\hline & & & & & \\
\hline GDP Level & 0.0 & 0.0 & 0.0 & 0.0 & 0.0 \\
\hline Inflation (Consumer Prices) & -0.3 & -0.1 & -0.1 & -0.1 & -0.2 \\
\hline Japan & & & & & \\
\hline GDP Level & 0.0 & 0.0 & 0.0 & 0.0 & 0.0 \\
\hline Inflation (Consumer Prices) & -0.1 & 0.0 & 0.0 & 0.0 & 0.0 \\
\hline European Union & & & & & \\
\hline GDP Level & 0.0 & 0.0 & 0.0 & 0.0 & 0.0 \\
\hline Inflation (Consumer Prices) & 0.3 & 0.2 & 0.2 & 0.2 & 0.3 \\
\hline Euro Area & & & & & \\
\hline GDP Level & 0.0 & 0.0 & 0.0 & 0.0 & 0.0 \\
\hline Inflation (Consumer Prices) & 0.6 & 0.4 & 0.4 & 0.4 & 0.4 \\
\hline Total OECD & & & & & \\
\hline GDP Level & 0.0 & 0.0 & 0.0 & 0.0 & 0.0 \\
\hline Inflation (Consumer Prices) & -0.1 & -0.1 & 0.0 & 0.0 & 0.0 \\
\hline Inflation (Consumer prices) & & & & & \\
\hline Canada & -0.1 & 0.0 & -0.1 & -0.1 & -0.1 \\
\hline France & 0.1 & 0.0 & 0.1 & 0.2 & 0.3 \\
\hline Germany & 0.5 & 0.0 & 0.2 & 0.3 & 0.4 \\
\hline Italy & 0.7 & 0.4 & 0.3 & 0.4 & 0.4 \\
\hline United Kingdom & -1.2 & -0.9 & -0.8 & -0.7 & -0.6 \\
\hline
\end{tabular}


Table A19. Ten percent Nominal Effective Depreciation

Deviations from baseline, in percent

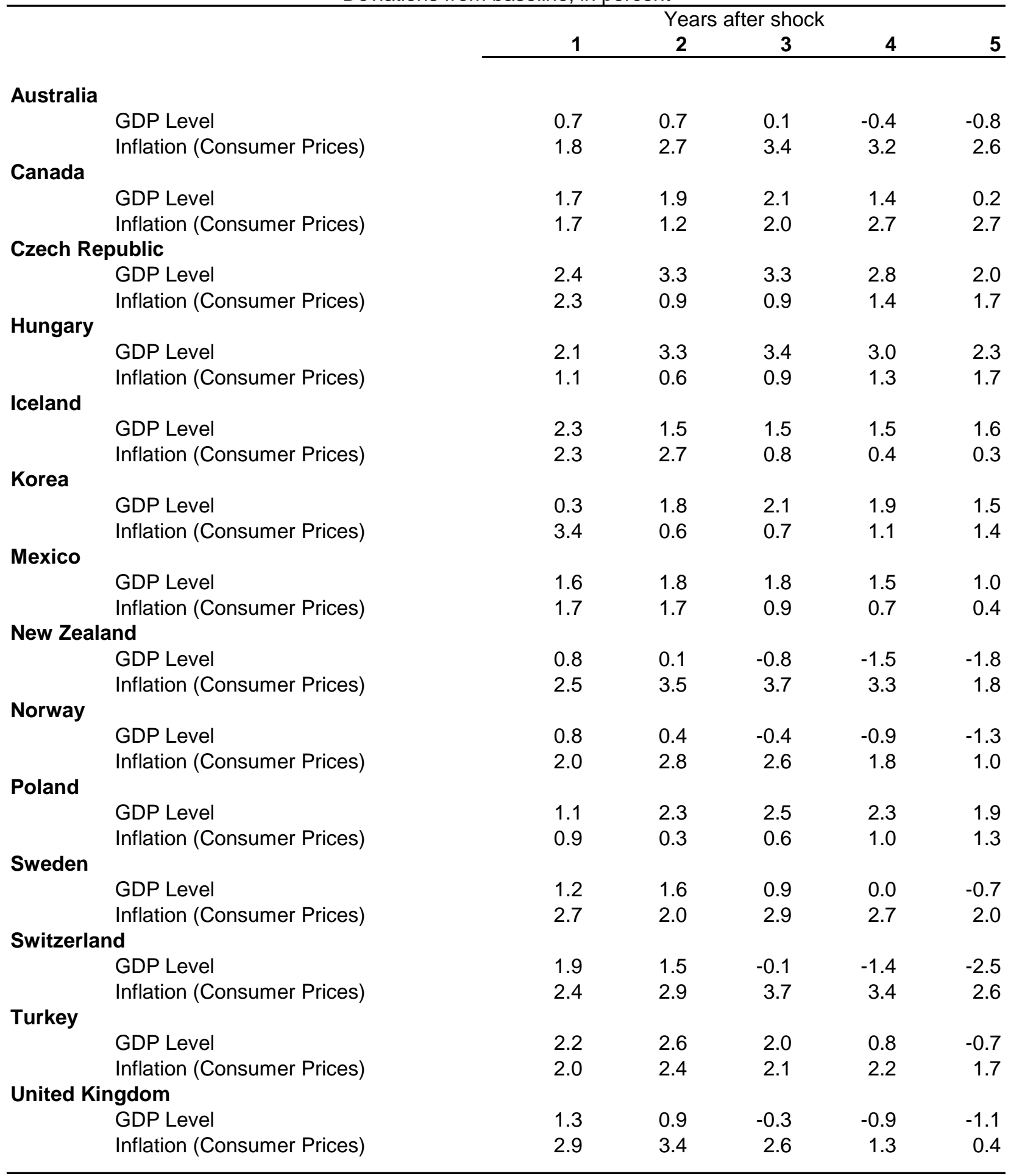

Real interest rates are held at their baseline level.

Real government spending and investment are held at their baseline levels. 
Table A20. Oil price increase

(50 per cent rise)

Deviations from baseline, in percent

\begin{tabular}{|c|c|c|c|c|c|}
\hline \multirow{3}{*}{ United States } & \multicolumn{5}{|c|}{ Years after shock } \\
\hline & \multirow[t]{2}{*}{1} & \multirow[t]{2}{*}{2} & \multirow[t]{2}{*}{3} & \multirow[t]{2}{*}{4} & 5 \\
\hline & & & & & \\
\hline GDP Level & -0.3 & -0.2 & 0.0 & 0.0 & 0.0 \\
\hline Inflation (Consumer Prices) & 0.5 & 0.2 & 0.1 & 0.1 & 0.1 \\
\hline Current account (\% GDP) & -0.2 & -0.2 & -0.2 & -0.1 & -0.1 \\
\hline Govt net lending (\% GDP) & -0.2 & -0.2 & -0.1 & -0.1 & -0.1 \\
\hline \multicolumn{6}{|l|}{ Japan } \\
\hline GDP Level & -0.4 & -0.3 & 0.1 & 0.3 & 0.1 \\
\hline Inflation (Consumer Prices) & 0.4 & 0.0 & 0.0 & 0.1 & 0.1 \\
\hline Current account (\% GDP) & -0.3 & -0.3 & -0.4 & -0.4 & -0.3 \\
\hline Govt net lending (\% GDP) & -0.3 & -0.2 & -0.2 & -0.1 & -0.2 \\
\hline \multicolumn{6}{|l|}{ European Union } \\
\hline GDP Level & -0.3 & -0.1 & 0.2 & 0.2 & 0.1 \\
\hline Inflation (Consumer Prices) & 0.6 & 0.2 & 0.2 & 0.3 & 0.3 \\
\hline Current account (\% GDP) & -0.2 & -0.1 & 0.0 & 0.1 & 0.1 \\
\hline Govt net lending (\% GDP) & -0.3 & -0.2 & -0.2 & -0.1 & -0.1 \\
\hline \multicolumn{6}{|l|}{ Euro Area } \\
\hline GDP Level & -0.4 & -0.2 & 0.2 & 0.2 & 0.1 \\
\hline Inflation (Consumer Prices) & 0.6 & 0.2 & 0.1 & 0.2 & 0.3 \\
\hline Current account (\% GDP) & -0.3 & -0.1 & 0.0 & 0.0 & 0.0 \\
\hline Govt net lending (\% GDP) & -0.3 & -0.3 & -0.2 & -0.1 & -0.1 \\
\hline \multicolumn{6}{|l|}{ Total OECD } \\
\hline GDP Level & -0.3 & -0.2 & 0.1 & 0.2 & 0.1 \\
\hline Inflation (Consumer Prices) & 0.6 & 0.2 & 0.1 & 0.2 & 0.2 \\
\hline Current account (\% GDP) & -0.1 & -0.1 & -0.1 & 0.0 & 0.0 \\
\hline Govt net lending (\% GDP) & -0.2 & -0.2 & -0.1 & -0.1 & -0.1 \\
\hline \multicolumn{6}{|l|}{ GDP Levels } \\
\hline Canada & 0.0 & 0.3 & 0.5 & 0.4 & 0.2 \\
\hline France & -0.2 & -0.1 & 0.2 & 0.2 & 0.2 \\
\hline Germany & -0.6 & 0.0 & 0.7 & 0.6 & 0.4 \\
\hline Italy & -0.3 & -0.4 & 0.1 & 0.2 & 0.2 \\
\hline United Kingdom & -0.1 & 0.0 & 0.1 & 0.1 & -0.1 \\
\hline \multicolumn{6}{|l|}{ Inflation (Consumer prices) } \\
\hline Canada & 0.1 & -0.1 & 0.2 & 0.5 & 0.6 \\
\hline France & 0.6 & 0.1 & 0.1 & 0.2 & 0.3 \\
\hline Germany & 0.4 & -0.1 & -0.2 & 0.0 & 0.2 \\
\hline Italy & 1.0 & 0.2 & 0.0 & 0.1 & 0.1 \\
\hline United Kingdom & 0.4 & 0.3 & 0.4 & 0.6 & 0.5 \\
\hline \multicolumn{6}{|c|}{$\begin{array}{l}\text { Taking into account a gradual increase in imports in Africa and Middle-East, } \\
\text { Nominal exchange rates are fixed. } \\
\text { Real interest rates are held at their baseline level. } \\
\text { Real government spending and investment are held at their baseline levels. }\end{array}$} \\
\hline
\end{tabular}


Table A21. Commodity price increase

(20 percent rise in non-oil commodity prices) Deviations from baseline, in percent

\begin{tabular}{|c|c|c|c|c|c|}
\hline \multirow{3}{*}{ United States } & \multicolumn{4}{|c|}{ Years after shock } & \multirow[b]{2}{*}{5} \\
\hline & \multirow[t]{2}{*}{1} & \multirow[t]{2}{*}{2} & \multirow[t]{2}{*}{3} & \multirow[t]{2}{*}{4} & \\
\hline & & & & & \\
\hline GDP Level & -0.2 & -0.1 & 0.0 & 0.1 & 0.1 \\
\hline Inflation (Consumer Prices) & 0.2 & 0.0 & 0.0 & 0.0 & 0.0 \\
\hline Current account (\% GDP) & 0.0 & -0.1 & 0.0 & 0.0 & 0.0 \\
\hline Govt net lending (\% GDP) & -0.1 & -0.1 & 0.0 & 0.0 & 0.0 \\
\hline \multicolumn{6}{|l|}{ Japan } \\
\hline GDP Level & -0.3 & -0.2 & 0.0 & 0.1 & 0.0 \\
\hline Inflation (Consumer Prices) & 0.2 & -0.2 & 0.0 & 0.1 & 0.0 \\
\hline Current account (\% GDP) & -0.2 & -0.3 & -0.3 & -0.4 & -0.4 \\
\hline Govt net lending (\% GDP) & -0.1 & -0.1 & -0.1 & -0.1 & -0.1 \\
\hline \multicolumn{6}{|l|}{ European Union } \\
\hline GDP Level & -0.2 & -0.2 & -0.1 & -0.1 & -0.1 \\
\hline Inflation (Consumer Prices) & 0.3 & 0.2 & 0.2 & 0.2 & 0.2 \\
\hline Current account (\% GDP) & 0.1 & 0.0 & 0.1 & 0.1 & 0.1 \\
\hline Govt net lending (\% GDP) & -0.1 & -0.1 & -0.1 & -0.1 & -0.1 \\
\hline \multicolumn{6}{|l|}{ Euro Area } \\
\hline GDP Level & -0.2 & -0.2 & -0.1 & -0.1 & -0.1 \\
\hline Inflation (Consumer Prices) & 0.3 & 0.2 & 0.1 & 0.1 & 0.2 \\
\hline Current account (\% GDP) & 0.0 & 0.0 & 0.1 & 0.1 & 0.1 \\
\hline Govt net lending (\% GDP) & -0.1 & -0.1 & -0.1 & -0.1 & -0.1 \\
\hline \multicolumn{6}{|l|}{ Total OECD } \\
\hline GDP Level & -0.2 & -0.2 & 0.0 & 0.0 & 0.0 \\
\hline Inflation (Consumer Prices) & 0.3 & 0.1 & 0.1 & 0.1 & 0.1 \\
\hline Current account (\% GDP) & 0.0 & 0.0 & 0.0 & 0.0 & 0.0 \\
\hline Govt net lending (\% GDP) & -0.1 & -0.1 & -0.1 & 0.0 & 0.0 \\
\hline \multicolumn{6}{|l|}{ GDP Levels } \\
\hline Canada & 0.0 & 0.1 & 0.2 & 0.3 & 0.2 \\
\hline France & -0.1 & -0.1 & 0.0 & 0.1 & 0.2 \\
\hline Germany & -0.3 & -0.2 & 0.1 & 0.1 & 0.1 \\
\hline Italy & -0.2 & -0.3 & -0.2 & -0.2 & -0.2 \\
\hline United Kingdom & -0.1 & -0.2 & -0.2 & -0.2 & -0.2 \\
\hline \multicolumn{6}{|l|}{ Inflation (Consumer prices) } \\
\hline Canada & 0.2 & 0.1 & 0.1 & 0.2 & 0.2 \\
\hline France & 0.1 & -0.1 & -0.1 & -0.1 & 0.0 \\
\hline Germany & 0.1 & 0.0 & -0.1 & 0.0 & 0.1 \\
\hline Italy & 0.4 & 0.3 & 0.1 & 0.1 & 0.1 \\
\hline United Kingdom & 0.3 & 0.3 & 0.2 & 0.2 & 0.2 \\
\hline
\end{tabular}

Nominal exchange rates are fixed.

Real interest rates are held at their baseline level.

Real government spending and investment are held at their baseline levels. 


\section{ECONOMICS DEPARTMENT \\ WORKING PAPERS}

305. Fiscal Implications of Ageing: Projections of Age-Related Spending Thai-Thanh Dang, Pablo Antolin and Howard Oxley

304. The Width of the Intra-European Economic Borders Alain de Serres, Peter Hoeller and Christine de la Maisonneuve

303. Surveillance of Tax Policies: a Synthesis of Findings in Economic Surveys (July 2001) Paul Van den Noord and Christopher Heady

302. Reforming the Tax System in Portugal

(July 2001) Chiara Bronchi and José Gomes-Santos

301. Tax Systems in European Union Countries (June 2001) Isabelle Joumard

300. Encouraging Environmentally Sustainable Growth in Belgium (June 2001) Paul O’Brien, David Carey, Jens Høj, Andreas Woergoetter

299. Encouraging Environmentally Sustainable Growth in Poland (June 2001) Grzegorz Peszko, Patrick Lenain

298. Tracking the Euro (June 2001) Vincent Koen, Laurence Boone, Alain de Serres, Nicola Fuchs

297. Firm Dynamics and Productivity Growth: A Review of Micro-evidence from OECD Countries (June 2001) Sanghoon Ahn

296. How should Norway Respond to Ageing? (May 2001) Pablo Antolín and Wim Suyker

295. How will Ageing Affect Finland? (May 2001) Pablo Antolín, Howard Oxley and Wim Suyker

294. Sectoral Regulatory Reforms in Italy: Framework and Implications (May 2001) Alessandro Goglio

293. Encouraging Environmentally Sustainable Growth: Experience in OECD Countries (May 2001) Paul O'Brien and Ann Vourc'h

292. Increasing Simplicity, Neutrality and Sustainability: A Basis for Tax Reform in Iceland (May 2001) Richard Herd and Thorsteinn Thorgeirsson

291. Options for Reforming the Tax System in Greece (April 2001) Chiara Bronchi

290. Encouraging Environmentally Sustainable Growth in Canada (March 2001) Ann Vourc'h

289. Encouraging Environmentally Sustainable Growth in Sweden (March 2001) Deborah Roseveare 


\section{ECO/WKP(2001)32}

288. Public Spending in Mexico: How to Enhance its Effectiveness (March 2001) Bénédicte Larre and Marcos Bonturi

287. Regulation in Services: OECD Patterns and Economic Implications (February 2001) Giuseppe Nicoletti

286. A Small Global Forecasting Model (February 2001) David Rae and David Turner

285. Managing Public Expenditure: Some Emerging Policy Issues and a Framework for Analysis (February 2001) Paul Atkinson and Paul van den Noord

284. Trends in Immigration and Economic Consequences (February 2001) Jonathan Coppel, Jean-Christophe Dumont and Ignazio Visco

283. Economic Growth: The Role of Policies and Institutions.

Panel Data Evidence from OECD Countries

(January 2001) Andrea Bassanini, Stefano Scarpetta and Philip Hemmings

282. Does Human Capital Matter for Growth in OECD Countries? Evidence from Pooled Mean-Group Estimates (January 2001) Andrea Bassanini and Stefano Scarpetta

281. The Tax System in New Zealand: An Appraisal and Options for Change (January 2001) Thomas Dalsgaard

280. Contributions of Financial Systems to Growth in OECD Countries (January 2001) Michael Leahy, Sebastian Schich, Gert Wehinger, Florian Pelgrin and Thorsteinn Thorgeirsson

279. House Prices and Economic Activity (January 2001) Nathalie Girouard and Sveinbjörn Blöndal

278. Encouraging Environmentally Sustainable Growth in the United States (January 2001) Paul O’Brien

277. Encouraging Environmentally Sustainable Growth in Denmark (January 2001) Paul O’Brien and Jens Høj

276. Making Growth more Environmentally Sustainable in Germany (January 2001) Grant Kirkpatrick, Gernot Klepper and Robert Price

275. Central Control of Regional Budgets : Theory with Applications to Russia (January 2001) John M. Litwack

274. A Post-Mortem on Economic Outlook Projections (December 2000) Vassiliki Koutsogeorgopoulou

273. Fixed Cost, Imperfect Competition and Bias in Technology Measurement: Japan and the United States (December 2000) Kiyohiko G. Nishimura and Masato Shirai

272. Entry, Exit, and Aggregate Productivity Growth: Micro Evidence on Korean Manufacturing (December 2000) Chin-Hee Hahn

271. The Tax System in Korea: More Fairness and Less Complexity Required (December 2000) Thomas Dalsgaard 